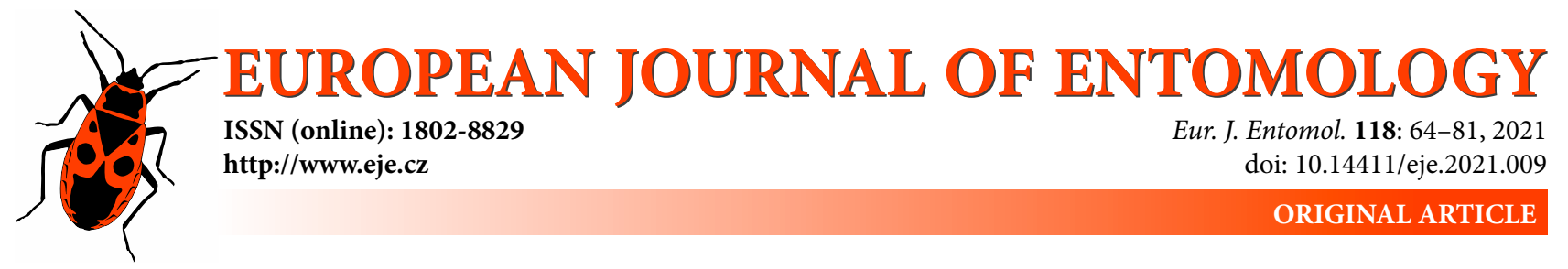

\title{
Three new species of the Xylophanes crotonis species-group (Lepidoptera: Sphingidae) from Colombia and a neotype designation for Xylophanes aristor
}

\author{
Yenny CORREA-CARMONA ${ }^{1,2}$, Alessandro GIUSTI ${ }^{3}$, JeAn HAXAIRE ${ }^{4}$, Rodolphe ROUGeRIE ${ }^{5}$ and IAN J. KITCHING ${ }^{3}$ \\ ${ }^{1}$ CEFE, Univ Montpellier, CNRS, EPHE, IRD, Univ Paul Valéry Montpellier 3, Montpellier, France; \\ e-mail: yennycorreacarmona@gmail.com \\ ${ }^{2}$ Grupo de Entomología Universidad de Antioquia (GEUA), Medellín AA 1226, Colombia \\ ${ }^{3}$ Insects Division, Life Sciences Department, Natural History Museum, Cromwell Road, London SW7 5BD, UK; \\ e-mails: a.giusti@nhm.ac.uk, i.kitching@nhm.ac.uk \\ ${ }^{4}$ Correspondent of the Muséum national d'Histoire naturelle, Paris, France; e-mail: jeanhaxaire@sfr.fr \\ ${ }^{5}$ Institut de Systématique, Evolution, Biodiversité (ISYEB), Muséum national d'Histoire naturelle, CNRS, Sorbonne Université, \\ EPHE, Université des Antilles, Paris, France; e-mail: rodolphe.rougerie@mnhn.fr \\ ORCiD. Yenny Correa-Carmona: 0000-0003-0209-8729; Alessandro Giusti: 0000-0003-1240-0768; Jean Haxaire: \\ 0000-0001-6375-3892; Rodolphe Rougerie: 0000-0003-0937-2815; lan J. Kitching: 0000-0003-4738-5967
}

Key words. Lepidoptera, Sphingidae, Colombia, DNA barcoding, neighbor-joining tree, neotype, new species, species
delimitation, taxonomy, Xylophanes crotonis species-group

\begin{abstract}
Three new species of the hawkmoth genus Xylophanes Hübner, 1819 from Colombia are described based on morphological characters and DNA barcodes: Xylophanes camilae Correa-Carmona \& Giusti sp. n., Xylophanes pijao Giusti \& CorreaCarmona sp. n., and Xylophanes tayrona Correa-Carmona \& Giusti sp. n. The new species are compared with the most morphologically similar species within the informal Xylophanes crotonis species-group: Xylophanes aristor (Boisduval, 1870), Xylophanes crotonis (Walker, 1856) and Xylophanes huloti Haxaire \& Vaglia, 2008. Diagnoses, distribution maps, photographs of genital structures and habitus are provided for each new species. In addition, a dichotomous key is provided to identify the new species and the most morphologically similar species within the group. To stabilize the nomenclature and fix the taxon concept, a neotype is designated for Xylophanes aristor.
\end{abstract}

ZooBank Article Registration: http://zoobank.org/urn:Isid:zoobank.org:pub:CA12ABAE-D1FD-417D-9F72-5472F5FECF8A

\section{INTRODUCTION}

The hawkmoths (family Sphingidae) are one of the most charismatic groups of insects owing to their large size, beauty and importance as pollinators in the tropics. Consequently, they are one of the best studied groups of moths (Kitching \& Cadiou, 2000). The Sphingidae family includes over 1,600 species, around $28 \%$ of which are found in the Neotropics and around $12 \%$ in Colombia (Correa-Carmona et al., 2015; Kitching et al., 2018; Kitching, 2020). In the last 30 years, interest in the Neotropical fauna and improved access to previously unexplored areas has increased the number of publications that document the biodiversity of South American hawkmoths among which are the annotated checklists of the hawkmoths of French Guiana (Haxaire \& Rasplus, 1986, 1987), Bolivia (Haxaire \& Herbin, 1999, 2000, 2001) and Argentina (Moré et al., 2005), or the recent survey of Colombian sphingids by
Correa-Carmona et al. (2015). As a result, the number of species of hawkmoths known from the Neotropics has increased greatly, and new species continue to be found, exemplified by the recent discoveries by Haxaire et al. (2015) and Haxaire \& Mielke (2018).

Xylophanes Hübner, 1819 is the most diverse genus of hawkmoths in the Neotropics, with 108 species and 11 subspecies described (Kitching et al., 2018). Among these, several species groups require an integrative approach combining comparative morphological and molecular analyses, as well as biogeography, to clarify their taxonomy. One of these, the Xylophanes crotonis (Walker, 1856) species-group, currently comprises 11 species based on morphological and molecular criteria, and includes the largest number of recently described species, most of which come from the Andean region (Haxaire, 2003; Haxaire \& Vaglia, 2004, 2008; Vaglia \& Haxaire, 2009) 
(the term "species-group" is used here to indicate an informal grouping of species that are considered to be each other's closest relatives, and which may or may not have an explicit phylogenetic justification). The species of this group are large hawkmoths characterized by a green upperside ground coloration (but which frequently fades to brown with age; Xylophanes kiefferi Cadiou, 1995 is a notable exception in being brown even when fresh) and a yellow to orange underside ground colour; a forewing upperside with parallel, oblique lines that cross the wing from the posterior margin towards the apex, the number of which varies according to the species; and a black hindwing upperside with a series of pale-yellow triangular spots. Five species of this group have so far been recorded from Colombia: Xylophanes aristor (Boisduval, 1870), $X$. crotonis, X. kiefferi, X. vagliai Haxaire, 2003 and $X$. virescens (Butler, 1875). However, as a result of investigations by the authors of specimens in museum collections and the results of recent survey expeditions, three new species of the Xylophanes crotonis species-group have been discovered in Colombia and are described below; two come from the Sierra Nevada de Santa Marta (Magdalena department) and one from the Nevado del Tolima ("Monte Tolima") in the Central Andes.

\section{MATERIAL AND METHODS}

After study of all the species within the $X$. crotonis speciesgroup, we considered that the Colombian specimens we suspected to represent new species most closely resembled the three species $X$. aristor, $X$. crotonis and $X$. huloti in their habitus (wing patterns and coloration). These species were then considered thoroughly for our comparative morphological analysis. However, because preliminary analyses of DNA barcode data revealed that morphologically similar species were not necessarily the nearest genetically, our genetic distances analyses included all representatives of the $X$. crotonis species-group for which DNA barcodes were available to us.

\section{Morphology, imaging and mapping}

For morphological comparisons and for the description of the new species, 32 specimens (all males) representing the three new species and the three most resembling species of the $X$. crotonis species-group were thoroughly examined. Four specimens of $X$. aristor, four specimens of $X$. crotonis, and three specimens of $X$. huloti were compared with nine specimens of $X$. pijao sp. n., seven specimens of $X$. camilae sp. n., and five specimens of $X$. tayrona sp. $\mathrm{n}$. In addition, for all described species within the $X$. crotonis species-group,the type specimens, and original description (of $X$. huloti), along with the photographs available from the online Sphingidae Taxonomic Inventory (Kitching, 2020; http:// sphingidae.myspecies.info) were used, together with the images available in BOLD (www.boldsystems.org; Ratnasingham \& Hebert, 2007) for the specimens used in the DNA barcoding analysis and listed in Table 1.

To generate the diagnoses, the shape and colour of the wings, and characters of the oblique lines of the forewing uppersides, the dorsal longitudinal lines of the abdomen, and coloration of the tegulae were used. These are the most commonly considered habitus characters that have been used previously to separate species within the Xylophanes crotonis-group. Additionally, detailed descriptions of the male genitalia were made. Despite that they are overall very similar in the Xylophanes crotonis-group, some characters of the uncus, harpe and the phallus allow the different species in the group to be separated and compared.

Extraction of the male genitalia was performed by removing the abdomens of two specimens and macerating them for about three hours in a $10 \%$ aqueous solution of potassium hydroxide to digest the soft tissues. After maceration, the abdomens were dissected and the genitalia cleaned and stained in saturated chlorazol black ( $75 \%$ ethanol) for about $25 \mathrm{~s}$. The preparations were preserved in glycerol-filled microcentrifuge tubes to allow for three-dimensional analysis of the structures. The genitalia were photographed using a Canon E05 5DSR digital camera, with a Canon MP-E $65 \mathrm{~mm} \mathrm{f} / 2.8$ 1-5X macro lens, then stacking the images using the Helicon Focus imaging system and software v. 7.5.1 (Helicon Soft Ltd.; https://www.heliconsoft.com/) to obtain a better depth of field in the final image. The occurrence maps were constructed using ArcMap 10.4.1 (ESRI, 2016) and a digital elevation model of the Shuttle Radar Topography Mission, which has a resolution of $250 \mathrm{~m}$ (Jarvis et al., 2008).

\section{DNA barcoding and data analysis}

In addition to examination and comparison of adult morphology, we also analysed the standard DNA barcode region (part of the mtDNA gene coding for cytochrome oxidase subunit I; Hebert et al., 2003) for specimens representing all 11 described species of the $X$. crotonis species-group and two of the new species for which recent material was available to us.

Twelve recently collected specimens from Colombia were processed in the molecular biology facility (Service de Systématique Moléculaire) of the MNHN (Muséum national d'Histoire naturelle). DNA extraction was carried out using a Macherey-Nagel NucleoSpin ${ }^{\circledR} 96$ tissue kit, and following the manufacturer's protocol, applying a semi-automated procedure implemented on an Eppendorf Liquid Handling Workstation epMotion ${ }^{\circledR} 7075$ VAC. We used the standard Lepidoptera primers LepF1 and LepR1 (Hebert et al., 2004) targeting the entire DNA barcode region $(658 \mathrm{bp})$ in PCR solutions of $20 \mu \mathrm{L}$ containing $2 \mu \mathrm{L}$ of $10 \mathrm{X}$ CoralLoad PCR buffer, $2 \mu \mathrm{L}$ of dNTP $(6.6 \mathrm{mM}), 0.6 \mu \mathrm{L}$ of each primer $(10 \mathrm{mM}), 0.2 \mu \mathrm{L}$ of DNA Taq Polymerase $(5 \mathrm{U} / \mu \mathrm{L})$ from Qiagen, $2 \mu \mathrm{L}$ of DNA template and $13.2 \mu \mathrm{L}$ of pure water. PCR conditions were: $94^{\circ} \mathrm{C}$ for $5 \mathrm{~min}$, followed by 35 cycles of $94^{\circ} \mathrm{C}$ for $30 \mathrm{~s}, 54^{\circ} \mathrm{C}$ for $40 \mathrm{~s}$ and $72^{\circ} \mathrm{C}$ for $1 \mathrm{~min}$, with a final $10 \mathrm{~min}$ extension at $72{ }^{\circ} \mathrm{C}$. PCR products were examined on $2 \%$ agarose gel and only successfully amplified DNA templates were sent for Sanger sequencing using an ABI 3730XL sequencer at the Eurofins MWG Operon sequencing facilities (Ebersberg, Germany).

We combined the DNA barcodes of these newly sequenced samples with those of a set that represent species in the Xylophanes crotonis species-group generated during the course of the global DNA barcoding campaign for family Sphingidae, coordinated by RR, JH and IJK (Lepidoptera Barcode of Life: Sphingidae [http://www.lepbarcoding.org/Sphingidae/index.php]). In total, the DNA barcode dataset used comprises 90 sequences (Table 1) and includes the DNA barcodes of the holotypes and several paratypes of the species $X$. alexandre $i$ Haxaire \& Vaglia, 2009, X. huloti Haxaire \& Vaglia, 2008 and X. vagliai Haxaire, 2003, as well as a partial (552 bp) sequence from the pre-1875 lectotype of $X$. virescens (Butler, 1875), which was obtained using the protocol in Lees et al. (2010). In total, all species in the $X$. crotonis species-group are represented in this dataset. All specimen and sequence data for the records listed in Table 1 are available in the public dataset DS-XYLOCOL1 (dx.doi.org/ 10.5883/ DS-XYLOCOL1) in BOLD (Barcode of Life Datasystems, www. boldsystems.org; Ratnasingham \& Hebert, 2007). DNA sequences are also publicly accessible on GenBank with accession numbers as listed in Table 1. 
Table 1. List of the 90 records used for the DNA barcoding analysis. PT - paratype, HT - holotype, LT - lectotype, NT - neotype. Institution storing abbreviations: CJHL - Collection of Jean Haxaire, Laplume, France; EMEM - Entomologisches Museum Eitschberger, Marktleuthen, Germany; IAVH - Institute Alexander von Humboldt, Bogota, Colombia IMQC - Insectarium of Montréal, Québec, Canada; MNHN - Muséum national d'Histoire naturelle, Paris, France; NHMUK - Natural History Museum, London, UK; SMCR - Sphingidae Museum, Orlov, Czech Republic; CEUA - Entomological Collection of Universidad de Antioquia, Medellín, Colombia. Samples in bold were newly generated in this study.

\begin{tabular}{|c|c|c|c|c|c|c|c|}
\hline BOLD Sample ID & GenBank Accession & Species & Sex & Type status & Country & Elev. $(\mathrm{m})$ & Institution storing \\
\hline BC-Hax1018 & MN796395 & $X$. alexandrei & $\mathrm{M}$ & & Ecuador & 2900 & CJHL \\
\hline BC-Mel1195 & HQ581002 & $X$. alexandrei & M & & Ecuador & 2400 & SMCR \\
\hline BC-Mel1210 & HQ977188 & $X$. alexandrei & M & & Ecuador & 2400 & SMCR \\
\hline BC-Mel2492 & MN796417 & X. alexandrei & M & & Ecuador & 3000 & SMCR \\
\hline BC-Hax1003 & MN796369 & X. alexandrei & $\mathrm{M}$ & & Peru & 2000 & CJHL \\
\hline BC-Hax1013 & MN796378 & $X$. alexandrei & M & PT & Peru & & CJHL \\
\hline BC-Hax1014 & MN796376 & $X$. alexandrei & M & PT & Peru & & CJHL \\
\hline BC-Hax1015 & MN796379 & $X$. alexandrei & M & & Peru & 2000 & CJHL \\
\hline BC-Hax1016 & MN796380 & $X$. alexandrei & M & & Peru & 2000 & CJHL \\
\hline BC-Hax1019 & MN796409 & X. alexandrei & M & PT & Peru & 2350 & CJHL \\
\hline BC-Hax1020 & MN796367 & $X$. alexandrei & M & PT & Peru & 2000 & CJHL \\
\hline BC-Hax5063 & MN796397 & $X$. alexandrei & M & & Peru & 2450 & CJHL \\
\hline BC-Hax5066 & MN796398 & X. alexandrei & M & & Peru & 2450 & CJHL \\
\hline BC-Hax5067 & MN796364 & $X$. alexandrei & M & PT & Peru & 2350 & CJHL \\
\hline BC-Hax5068 & MN796352 & $X$. alexandrei & M & & Peru & 2450 & CJHL \\
\hline BC-Hax5069 & MN796389 & $X$. alexandrei & $\mathrm{M}$ & & Peru & 2450 & CJHL \\
\hline BC-Hax5070 & MN796375 & $X$. alexandrei & $M$ & & Peru & 2450 & CJHL \\
\hline BC-Mel1196 & HQ581003 & $X$. alexandrei & M & & Peru & 2800 & SMCR \\
\hline BC-Mel2542 & MN796414 & $X$. alexandrei & M & & Peru & 3100 & SMCR \\
\hline VAG-017 & MN796410 & $X$. alexandrei & M & HT & Peru & 0 & IMQC \\
\hline VAG-018 & MN796413 & X. alexandrei & M & PT & Peru & 0 & IMQC \\
\hline VAG-019 & MN796403 & $X$. alexandrei & M & PT & Peru & 0 & IMQC \\
\hline VAG-170 & MN796383 & $X$. alexandrei & M & PT & Peru & 0 & IMQC \\
\hline BC-Hax5462 & MW726209 & $X$. aristor & M & NT & Colombia & 2236 & MNHN \\
\hline BC-Mel2495 & MN796354 & $X$. aristor & M & & Colombia & & SMCR \\
\hline BC-Mel2496 & MN796386 & $X$. aristor & M & & Colombia & & SMCR \\
\hline BC-Mel2509 & MN796415 & $X$. aristor & M & & Venezuela & 2000 & SMCR \\
\hline $2 \mathrm{CO}-0222$ & MN796353 & X. camilae & M & PT & Colombia & 2738 & MNHN \\
\hline 2CO-1355 & MN796359 & X. camilae & M & HT & Colombia & 1600 & IAVH \\
\hline BC-Hax0945 & MN796388 & X. crotonis & M & & Bolivia & 1160 & CJHL \\
\hline BC-Hax0946 & MN796361 & $X$. crotonis & M & & Bolivia & 2170 & CJHL \\
\hline BC-Hax4581 & MN796377 & $X$. crotonis & M & & Bolivia & 2037 & CJHL \\
\hline BC-Hax4594 & MN796391 & $X$. crotonis & M & & Bolivia & 2000 & CJHL \\
\hline VAG-172 & MN796372 & $X$. crotonis & M & & Bolivia & 0 & IMQC \\
\hline VAG-175 & MN796402 & X. crotonis & M & & Bolivia & 0 & IMQC \\
\hline BC-Hax0940 & MN796351 & $X$. crotonis & $M$ & & Ecuador & & CJHL \\
\hline BC-Hax0941 & MN796356 & X. crotonis & M & & Ecuador & & CJHL \\
\hline BC-Hax0944 & MN796373 & X. crotonis & M & & Ecuador & 1250 & CJHL \\
\hline VAG-173 & MN796424 & X. crotonis & M & & Ecuador & 2400 & IMQC \\
\hline BC-Hax4593 & MN796399 & X. crotonis & $\mathrm{F}$ & & Peru & 1500 & CJHL \\
\hline BC-EMEM1471 & MN796422 & X. huloti & M & & Ecuador & 2000 & EMEM \\
\hline BC-Hax0996 & MN796371 & X. huloti & M & PT & Ecuador & 2300 & CJHL \\
\hline BC-Hax0997 & MN796412 & $X$. huloti & M & PT & Ecuador & 2350 & CJHL \\
\hline BC-Hax0998 & MN796405 & $X$. huloti & M & PT & Ecuador & 2300 & CJHL \\
\hline BC-Hax0999 & MN796394 & $X$. huloti & M & PT & Ecuador & 2300 & CJHL \\
\hline BC-Hax1000 & MN796387 & X. huloti & M & PT & Ecuador & 1915 & CJHL \\
\hline BC-Hax1002 & MN796384 & X. huloti & M & HT & Ecuador & 2300 & CJHL \\
\hline BC-Hax1017 & MN796418 & $X$. huloti & M & PT & Ecuador & 2330 & CJHL \\
\hline BC-Mel2493 & MN796363 & X. huloti & $M$ & & Ecuador & 2500 & SMCR \\
\hline BC-Mel2508 & MN796407 & X. huloti & M & & Ecuador & 2500 & SMCR \\
\hline BC-Hax1021 & MT456815 & X. kiefferi & M & PT & Ecuador & 2500 & CJHL \\
\hline BC-Hax1022 & JN678674 & X. kiefferi & $M$ & PT & Ecuador & 1860 & CJHL \\
\hline BC-Hax0955 & JN678675 & $X$. letiranti & M & PT & Costa Rica & 910 & CJHL \\
\hline BC-Hax0956 & MT456814 & $X$. letiranti & $M$ & PT & Costa Rica & 1440 & CJHL \\
\hline BC-Mel1206 & HQ581008 & $X$. letiranti & M & & Costa Rica & 1440 & SMCR \\
\hline BC-Hax5062 & MT456816 & $X$. letiranti & M & & Costa Rica & 2730 & CJHL \\
\hline BC-Hax1008 & MN796350 & X. rhodochlora & M & & Peru & 2350 & CJHL \\
\hline BC-Hax1009 & MN796390 & X. rhodochlora & M & & Peru & 2000 & CJHL \\
\hline BC-Hax1010 & MN796357 & X. rhodochlora & M & & Peru & 2000 & CJHL \\
\hline BC-Hax1011 & JN678696 & X. rhodochlora & M & & Peru & 2000 & CJHL \\
\hline BC-Hax1012 & MN796423 & X. rhodochlora & M & & Peru & 1280 & CJHL \\
\hline BC-Hax0831 & MN796392 & X. rhodotus & M & & Bolivia & 215 & CJHL \\
\hline BC-Hax4575 & MN796362 & X. rhodotus & M & & Bolivia & 1792 & CJHL \\
\hline BC-Hax4576 & MN796396 & $X$. rhodotus & M & & Bolivia & 1792 & CJHL \\
\hline BC-Hax4577 & GU703799 & X. rhodotus & M & & Bolivia & 1792 & CJHL \\
\hline BC-Hax4578 & MN796368 & X. rhodotus & M & & Bolivia & 1792 & CJHL \\
\hline BC-Hax1026 & HM384040 & X. schwartzi & M & & Ecuador & 2000 & CJHL \\
\hline BC-Hax1027 & HM384041 & X. schwartzi & M & & Ecuador & 2400 & CJHL \\
\hline BC-Hax1028 & MN796404 & X. schwartzi & M & & Ecuador & 2000 & CJHL \\
\hline BC-Hax1029 & JN678704 & X. schwartzi & M & & Ecuador & & CJHL \\
\hline $2 C 0-1139$ & MN796365 & X. tayrona & M & PT & Colombia & 2400 & IAVH \\
\hline RROU00395 & MN796385 & X. tayrona & $\mathbf{M}$ & PT & Colombia & 2400 & MNHN \\
\hline BC-YCC0015 & MN796401 & $X$. vagliai & M & & Colombia & 1837 & CEUA \\
\hline BC-YCC0017 & MN796366 & $X$. vagliai & M & & Colombia & 1837 & CEUA \\
\hline BC-YCC0021 & MN796406 & $X$. vagliai & M & & Colombia & 2194 & CEUA \\
\hline BC-YCC0023 & MN796411 & $X$. vagliai & M & & Colombia & 1150 & CEUA \\
\hline BC-YCC0024 & MN796370 & $X$. vagliai & M & & Colombia & 1575 & CEUA \\
\hline BC-YCC0025 & MN796421 & $X$. vagliai & $M$ & & Colombia & 2588 & CEUA \\
\hline BC-Hax1004 & MN796416 & $X$. vagliai & M & HT & Ecuador & 1770 & CJHL \\
\hline BC-Hax1005 & MN796381 & $X$. vagliai & M & PT & Ecuador & 1860 & CJHL \\
\hline BC-Hax1006 & MN796358 & X. vagliai & $M$ & PT & Ecuador & 1860 & CJHL \\
\hline BC-Hax1007 & MN796374 & $X$. vagliai & M & & Ecuador & 1969 & CJHL \\
\hline BC-Mel2512 & MN796400 & $X$. vagliai & M & & Ecuador & 1600 & SMCR \\
\hline BC-Mel2494 & MN796355 & $X$. virescens & M & & Colombia & 2800 & SMCR \\
\hline BC-Mel2499 & MN796393 & $X$. virescens & M & & Colombia & & SMCR \\
\hline BC-Mel2500 & MN796408 & $X$. virescens & M & & Colombia & & SMCR \\
\hline BC-Mel2507 & MN796420 & $X$. virescens & M & & Colombia & & SMCR \\
\hline NHM-SphTyp0002 & MN796382 & $X$. virescens & M & LT & Colombia & & NHMUK \\
\hline RROU00382 & MN796419 & $X$. virescens & M & & Colombia & 3200 & MNHN \\
\hline RROU00383 & MN796360 & $X$. virescens & M & & Colombia & 3000 & MNHN \\
\hline
\end{tabular}




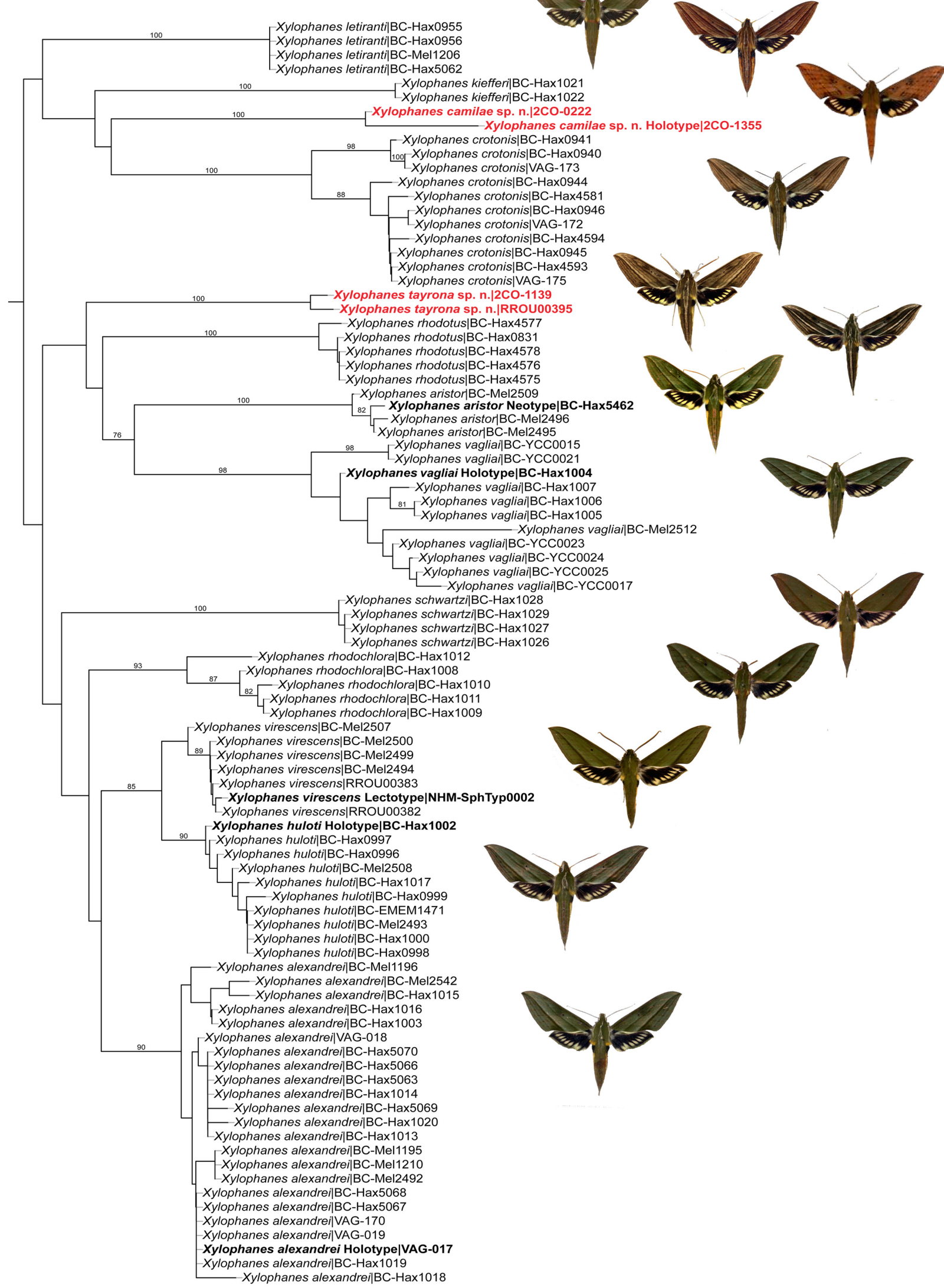

Tree scale: 0.01

Fig. 1. Neighbor-Joining tree of the 90 samples within the Xylophanes crotonis species-group built using MEGAX, midpoint-rooted; bootstrap values (1000 replicates) higher than $75 \%$ are indicated above branches. DNA barcodes of primary type specimens are emphasized in bold, those of the two new species with DNA barcodes are in red. The codes for each terminal refer to BOLD SampleID codes as listed in Table 1. All records are available on BOLD (www.boldsystems.org) in the dataset DS-XYLOCOL1. 
We ran a genetic distance analysis in BOLD (Ratnasingham \& Hebert, 2007), using the built-in analytical tools. We used MEGA $\mathrm{X}$ (Kumar et al., 2018) for tree representation of distances. We built a Neighbour-Joining (NJ) tree using uncorrected p-distances, uniform rates of substitution among sites and pairwise deletion option, and midpoint-rooted. Support for nodes was evaluated with 1000 bootstrap replications. The tree was exported in Newick format and further edited using the interactive Tree of Life (iTOL) web application (Letunic \& Bork, 2019).

\section{RESULTS}

\section{Comparative morphology}

A thorough comparison of the morphology of the habitus and male genitalia revealed consistent distinctive characters separating the specimens suspected to represent new species from closely resembling described species of the $X$. crotonis species-group. Additionally, because of the similarity of one of the new species described below with $X$. aristor (Boisduval, 1870), we investigated the taxonomic and nomenclatural status of this species and raised the need to designate a neotype to stabilize the nomenclature of the species under Article 75 of the International Code of Zoological Nomenclature (ICZN, 1999). This designation is carried out in the Taxonomy section below.

\section{DNA barcoding analyses}

The NJ tree (Fig. 1) shows that the DNA barcode clusters accurately match the species delineations derived from morphological comparisons. All recognized species form distinct clusters with high bootstrap support, and all were assigned distinct BINs (Barcode Index Numbers; Ratnasingham \& Hebert, 2013; see Table 1), except for $X$. alexandrei, $X$. huloti and $X$. virescens, which share the same BIN (BOLD: AAB4963), but nonetheless form distinct and exclusive clusters within it. This is presumably due to low levels of genetic divergence among them (as low as $0.5 \%$ between $X$. huloti and $X$. virescens). The internal (interspecific) nodes of the tree remain poorly supported. This is to be expected when analysing a single genetic marker and we consider the phylogenetic relationships of the species considered here to be unresolved and so refrain from discussing affinities among them. The minimum genetic distances between each of the two new species with DNA barcodes and other species within the $X$. crotonis speciesgroup are given in Table 2. Furthermore, our results include the DNA barcodes of the holotypes of $X$. vagliai, $X$. huloti, $X$. alexandrei, the lectotype of $X$. virescens, and the newly designated neotype (see below) of $X$. aristor. DNA barcodes of these type specimens ensure nomenclatural accuracy and stability for the future use of these names, especially if additional new cryptic species are later discovered in this species-group.

\section{Taxonomy}

\section{Genus Xylophanes Hübner, 1819}

Type species. Sphinx anubus Cramer, 1777 (designated by Rothschild \& Jordan, 1903: 675).

Isoples Hübner, 1819 [type species: Sphinx thyelia Linnaeus, 1758 (included by Hübner as theylia, an incorrect subsequent spelling), designated by Kirby, 1897: 24]; synonymized by Rothschild \& Jordan, 1903: 675.

Deilonche Grote, 1886 [type species: Sphinx tersa Linnaeus, 1771, designated by Kirby, 1897: 22 (for Dilonche, an unjustified emendation)]; synonymized by Rothschild \& Jordan, 1903: 675.

Dilonche Kirby, 1897 (an unjustified emendation of Deilonche Grote, 1886).

\section{Designation of the neotype of Chaerocampa aristor Xylophanes aristor (Boisduval, 1870)}

Chaerocampa [sic] aristor Boisduval, 1870.

Chaerocampa [sic] hortulanus Schaufuss, 1870; synonymized by Rothschild \& Jordan, 1903: 700.

The first published record of the species currently treated as Xylophanes aristor were the specimens referred to by Walker (1856: 133-134) in the description of Chaerocampa [sic] crotonis as "var. $\beta$ " and "var. $\gamma$ ", which were distinguished from the implicit "var. $\alpha$ " (i.e., the holotype of C. crotonis) primarily by the "thorax and abdomen with a whitish dorsal stripe" (Note: Chaerocampa is an incorrect subsequent spelling of Choerocampa Duponchel, 1835).

Chaerocampa aristor was formally described by Boisduval (1870: 69) based on two specimens stated to come from "Guatemala" ("Deux individus de Guatemala") and the editor of Boisduval's work, Paul de l'Orza, stated in the Introduction that the material was in his possession. However, it should be noted that this does not refer to the current country of Guatemala for Boisduval used "Guatemala" to refer to all of Central America between the borders of Mexico and Colombia (Lichy, 1968). Boisduval (1870) compared $C$. aristor with Chaerocampa tersa (Linnaeus, 1771) (now Xylophanes tersa) and noted, among other characters, that the upperside of the abdomen was olive-coloured with a greyish dorsal stripe ("'abdomen olivâtre en dessus, avec un raie dorsale grisâtre"). Boisduval (1875: 270) later repeated the description, with slightly altered and expanded phrasing, but now stating that the species was found in Colombia, as well as Guatemala ("Il se trouve au Guatemala et en Colombie"). He also indicated that the specimens were, after all, in his collection ("Coll. Bd.") but it is unclear whether this related to the specimens from both Guatemala and Colombia, or just to the latter, which he had presumably acquired in the time between the publications of the two works.

Table 2. Minimum p-distance between the two new species with DNA barcodes and other species in the Xylophanes crotonis species-group. The lowest values indicating genetic nearest neighbours are highlighted in bold.

\begin{tabular}{lccccccccccccc}
\hline & $\begin{array}{l}X . \\
\text { alexandrei }\end{array}$ & $\begin{array}{c}X . \\
\text { aristor }\end{array}$ & $\begin{array}{c}X . \\
\text { camilae }\end{array}$ & $\begin{array}{c}X . \\
\text { crotonis }\end{array}$ & $\begin{array}{c}X . \\
\text { huloti }\end{array}$ & $\begin{array}{c}X . \\
\text { kiefferi }\end{array}$ & $\begin{array}{c}X . \\
\text { letiranti }\end{array}$ & $\begin{array}{c}X . \\
\text { rhodochlora }\end{array}$ & $\begin{array}{c}X . \\
\text { rhodotus }\end{array}$ & $\begin{array}{c}X . \\
\text { schwartzi }\end{array}$ & $\begin{array}{c}X . \\
\text { tayrona }\end{array}$ & $\begin{array}{c}X . \\
\text { vagliai }\end{array}$ & $\begin{array}{c}X . \\
\text { virescens }\end{array}$ \\
\hline $\begin{array}{l}X . \text { camilae } \\
\text { sp. n }\end{array}$ & 4.2 & 6.8 & - & 5.2 & 4.2 & 4.7 & 5.2 & 4.2 & 5.3 & 5.3 & 6.2 & 6 & 3.8 \\
$\begin{array}{l}\text { X. tayrona } \\
\text { sp.n. }\end{array}$ & 3.1 & 4.4 & 6.2 & 4.4 & 3.6 & 5.4 & 4 & 3.5 & 3.5 & 4.1 & - & 3.5 & 3.3 \\
\hline
\end{tabular}



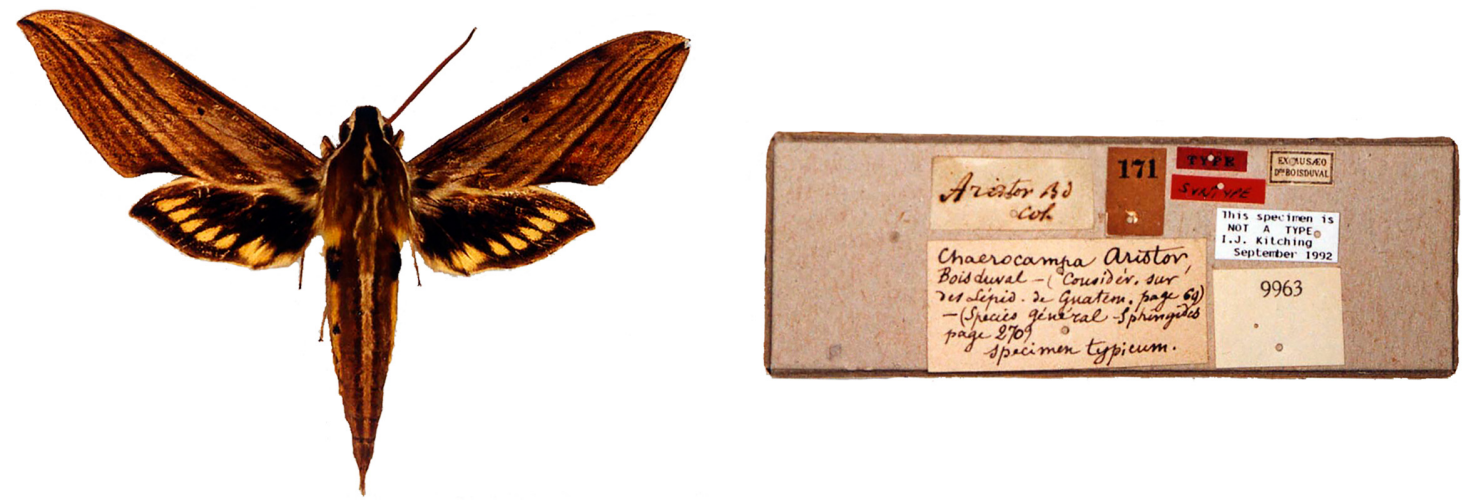

Fig. 2. Chaerocampa aristor specimen (“Aristor Bd. Col.") in the Carnegie Museum of Natural History (CMNH), Pittsburgh, Pennsylvania, USA.

Shortly after, Butler (1876: 563) was the first to indicate a close relationship between this species and Xylophanes crotonis. However, he clearly misinterpreted the two species because he stated that Chaerocampa aristor differed from Chaerocampa crotonis "in the colour of the primaries [forewings], the less distinct oblique lines crossing them, and the absence of the dorsal grey streak on the body". The dorsal longitudinal grey stripe, in particular, is a feature of what is now considered to be $X$. aristor and its absence is a contrasting feature of $X$. crotonis. However, it also seems that Butler (1876) was the first to question the veracity of the type locality of $C$. aristor, as he placed Guatemala in inverted commas, while not doing so for specimens in the British Museum from Venezuela, from the Dyson collection, which were, of course, those mentioned by Walker (1856) as "var. $\beta$ " and "var. $\gamma$ " of C. crotonis. Butler (1881: [1], pl. xv, Fig. 1) then illustrated one of these as a "typical" C. crotonis. In his review of Butler's (1876) revision, Maassen (1880: 56) recognized and clarified this catalogue of misinterpretations surrounding these names, stating " $p$. 563. Chaeroc. Aristor Bdv. ist $=$ Crotonis Wlk. (var.) = Crotonis Butler (Illustrat. Of typical spec. 1877)", while treating "Crotonis Wlk. (typus)" as a separate species.

In their monumental revision, however, Rothschild \& Jordan (1903: 699-700) synonymized Chaerocampa aristor with Xylophanes crotonis as a form, stating that "there are two forms occurring in the same countries and being connected by intergradations". They also summarized the previous taxonomic confusion: "Walker describes under crotonis both the form with abdominal dorsal stripe and the form without it. As he calls the former "var. $\beta$ " and "var. $\gamma$," Butler was certainly wrong in figuring it as typical crotonis. Maassen, l.c., has already drawn attention to the mistake. Walker described four varieties, but had only three specimens $(a-c)$, l.c."

Rothschild \& Jordan (1903) also synonymized Chaerocampa hortulanus Schaufuss, 1870 with Xylophanes crotonis $\mathrm{f}$. aristor, but did not indicate (by an asterisk) that they had examined the type. First published as a Moritz manuscript name and nomen nudum by Ménétriés (1857: 93), Chaerocampa hortulanus was described by Schaufuss (1870) based on two specimens from Venezuela in the collection of Carl Gotthelf Kaden, which are now in the Zoo- logical Institute, Saint Petersburg, Russia (Cadiou, 1995). Schaufuss's paper was published slightly later in 1870 than Boisduval's (Cadiou, 1995) and his description of C. hortulanus was quite brief: "Dem Chiron Dr. äusserst ähnlich, die Oberflügel aber oben intensiver grün, die Längsstreifen (sechs) viel deutlicher, besonders der oberste, und heller abschattirt" ("Very similar to Chiron Dr. [Druce], but the upper wings more intense green above, the (six) longitudinal stripes much clearer, especially the uppermost one, and paler shaded"). Quite how Rothschild \& Jordan (1903) identified this as Xylophanes crotonis form aristor without examining the types is something of a mystery. However, Cadiou (1995), who designated the lectotype of C. hortulanus, noted that this specimen bears a label on the back of which is written "crotonis Wlk,", "aristor $\beta$. pro" and "part." He went on to comment that "whoever wrote "aristor $\beta$. pro part." on the back of the lectotype's label wanted to refer to "var $\beta$." of Chaerocampa crotonis Walker (1856) which is aristor Boisduval" and accept the synonymy of $C$. hortulanus with $X$. aristor.

Lichy (1968: 38) reinstated Xylophanes aristor as a species separate from $X$. crotonis, noting that contrary to the statements of previous authors, there were no intermediates between the two. Lichy also commented that the two syntypes must not have been in a good condition because Boisduval described the forewings as having a pale olive tone ("Ailes supérieures d'une teinte olivâtre pâle"), rather than the deep green of fresh specimens ("Es más verde, algo como el verde pistacho, sumamente bello en las mariposas muy frescas") and attributed the colour change to "oxidation" in old specimens ("El descoloramiento en los especímenes viejos actúa también alterando el verde, "oxidándolo" en un gris bruno oliváceo").

Although d'Abrera (1987: 177) continued to treat X. aristor as a form of $X$. crotonis, its species status was accepted by Cadiou (1995: 502) and by all subsequent authors.

The true identity of Chaerocampa aristor, however, remains ambiguous, especially given the number of similar related species that have been described recently. Paul de l'Orza indicated that the original two syntypes were in his possession, but although it is believed that this collection passed to the MNHN in Paris, a thorough search there failed to uncover any specimens that could be assigned syntypic 

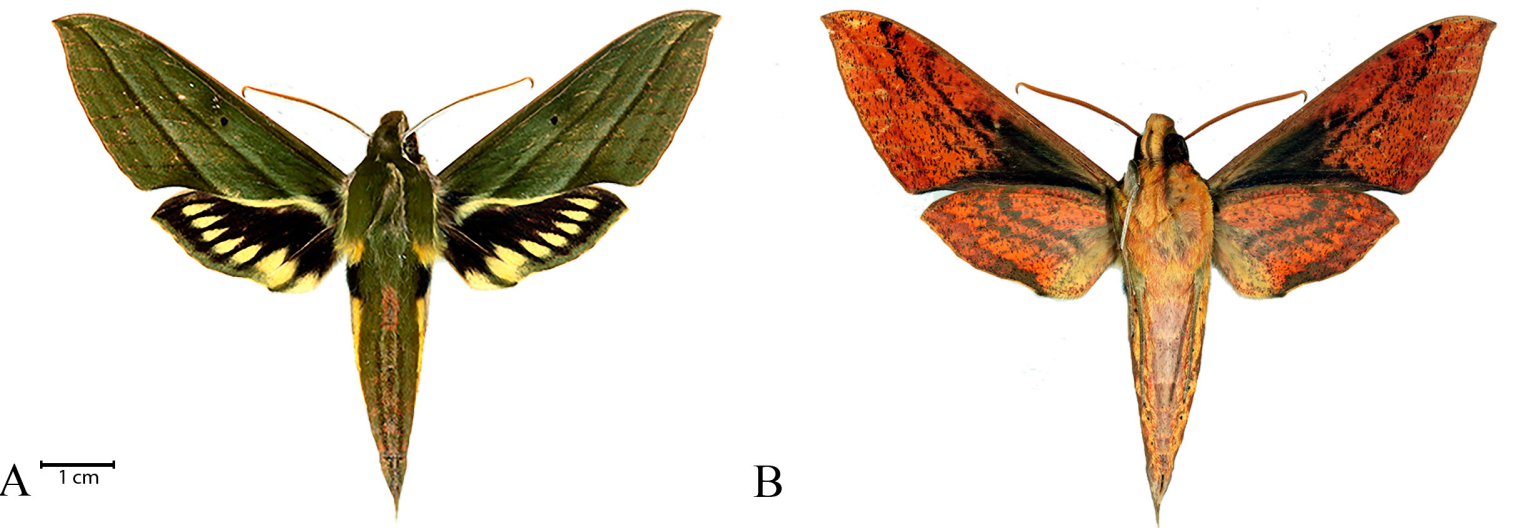

Fig. 3. Neotype of Chaerocampa aristor 3 BOLD SampleID BC-Hax5462. A - upperside; B - underside.

status. Boisduval (1875) later implied that he had at least one specimen in his collection. His collection passed via Charles Oberthür and B. Preston Clark to the Carnegie Museum of Natural History (CMNH), Pittsburgh, Pennsylvania, USA. A search of this collection yielded a male (Fig. 2) with a label in Boisduval's handwriting that reads "Aristor Bd. Col." Another handwritten label (but not in Boisduval's handwriting; whose has not been determined) implies that it is a type specimen. However, if "Col." is correctly interpreted as "Colombia", then this moth is not one of the two "Guatemala" syntypes and Boisduval's (1870) concept of "Guatemala" did not include Colombia (Lichy, 1968). It is most probably the Colombian specimen referred to by Boisduval (1875) and acquired by him between 1870 and 1875. For this reason, during a visit to the CMNH in September 1992, IJK added a label stating he did not consider this specimen to be type material.

The current whereabouts of the two syntypes of $C$. aristor are unknown. Rothschild \& Jordan (1903) indicated that they had seen the type when it was in Oberthür's collection but it would seem most likely that the moth they examined was the non-type Colombian specimen. No subsequent specimens of Xylophanes aristor have been forthcoming from Guatemala (or any Central American country), either in the literature or in any of the numerous collections, both public and private, examined by us and so we consider the type locality to be erroneous. In recent years, the name $X$. aristor has been applied to a species that was believed to occur in Colombia and Venezuela, as well as Ecuador (Cadiou, 1995: Figs 9-10). However, given that molecular analysis has demonstrated that there is a second species of this group in Colombia (see below) and that the populations in Ecuador most likely represent a further undescribed species (Krutov et al., 2021), we consider it necessary to designate a neotype to fix the concept of Chaerocampa aristor.

We did not select the CMNH specimen (Fig. 2) as the neotype because of its ambiguous and vague locality data ("Col.") and lack of supporting DNA barcode. Instead, we hereby designate the following DNA barcoded male specimen (BOLD SampleID BC-Hax5462) in the collection of Jean Haxaire, to be deposited in the MNHN as the neotype of Chaerocampa aristor (Fig. 3). It bears the locality data label: Colombia, Boyacá, Pajarito, Alto de Virgen, 2236m, $5.433,-72.7,1 . i v .2019$, leg. Daniel Herbin et al. This fixes and localizes the type locality of Xylophanes aristor as the southeastern slopes of the Cordillera Oriental near Lago de Tota, Boyacá Department, Colombia $\left(\approx 5.43^{\circ} \mathrm{N}, 72.70^{\circ} \mathrm{W}\right)$.

DNA barcode. Four DNA barcodes are currently available for $X$. aristor (Table 1), including that of the neotype, another from Colombia (with the same collecting data as the neotype), and a third from Venezuela (December 1997; Merida State, La Azulita, $2000 \mathrm{~m}$ ). Together, they form the BIN BOLD:ABX1349 (Dmax $=0.51 \%$ ), the nearest neighbor of which is $X$. vagliai (BIN BOLD:AAE4809) at $2.63 \%$ distance (see Fig. 1).

Distribution. In Colombia, Xylophanes aristor is currently known from Valle del Cauca, Boyacá (type locality) and Cundinamarca departments. In Venezuela, Lichy (1968) noted that the species occurs at higher elevations (above $1600 \mathrm{~m}$ ) in the Cordillera de Mérida (Mérida and Táchira states) and the western part of the Cordillera de la Costa (Aragua and Distrito Federal states). There are also specimens in coll. J. Haxaire from $1500 \mathrm{~m}$ in Barinas state. Lichy (1968) considered a single specimen from low elevation $(250 \mathrm{~m})$ in Carabobo state to be a stray.

\section{Species descriptions \\ Xylophanes camilae Correa-Carmona \& Giusti, sp. n.}

ZooBank taxon LSID:

8DA3D4EF-AD41-466C-9C60-C0473C2AFE07

\section{Description.}

Body length of $49 \mathrm{~mm}$.

Head and thorax. Upperside olive-green, pale greenishbrown in older specimens. Underside pale orange-yellow; orange colour and dark areas and lines more evident than in $X$. crotonis.

Wings. Wingspan of $89 \mathrm{~mm}$. Upperside olive-green, pale greenish-brown in older specimens; and underside pale orange-yellow; orange colour and dark areas and lines more evident than in $X$. crotonis. Forewings: Apex acute, slightly falcate; outer margin entire. Upperside discal cell with a small dark diffuse patch basally, a larger patch just beyond distal end and scattered black scales within; discal 

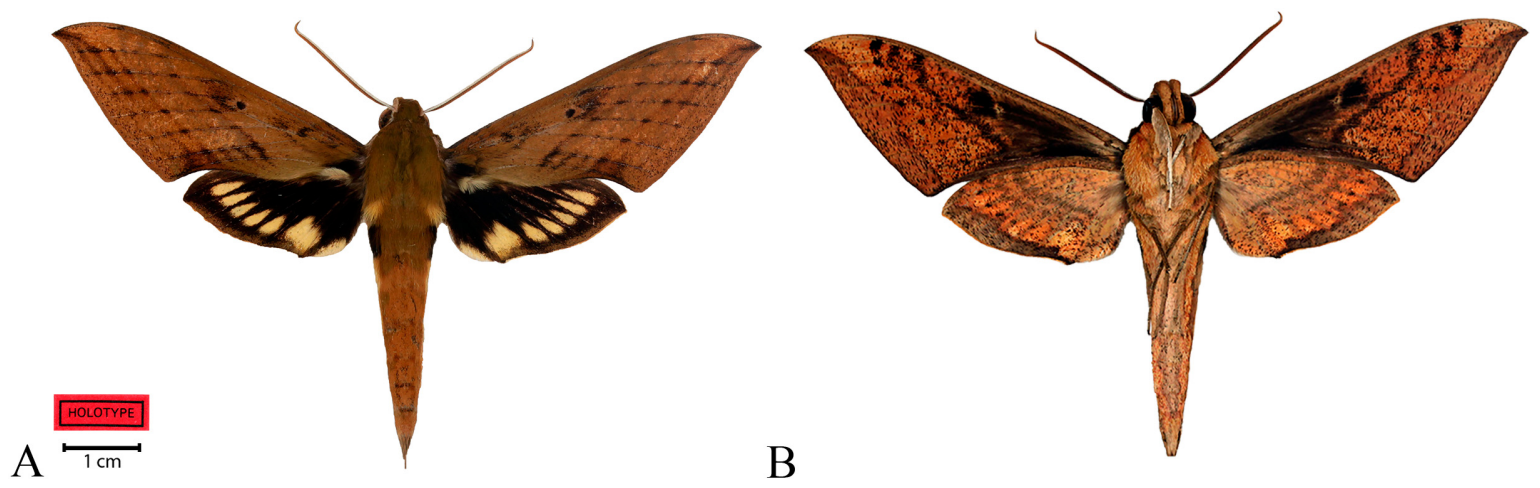

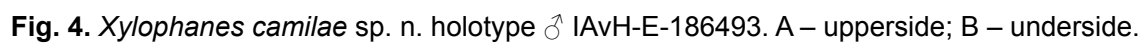

spot large, discrete and black; six parallel oblique lines, three medial, three postmedial, all very weak but highlighted by black dots in veins $\mathrm{Rs}_{4}$ to $1 \mathrm{~A}+2 \mathrm{~A}$, those one veins $\mathrm{CuA}_{2}$ and $1 \mathrm{~A}+2 \mathrm{~A}$ merging transversely into one another and area between them darker; outer two postmedial lines merging at apex to form a short apical streak; submarginal line represented by scattered black scales. Underside extreme base pale, otherwise basal half black except for paler orange costal area and oval discal spot, which is pale with a dark centre. Three black medial lines, the basalmost thick, irregular and continuous from the posterior margin to the costa, the other two represented by series of largely discontinuous black spots on the veins; marginal patch paler, inner edge pale brown, slightly produced inward on vein $\mathrm{M}_{2}$, including numerous short black dashes arranged roughly parallel to outer margin. Hindwings: Upperside black, slightly falcate apically, with a series of elongate bright pale-yellow ovoid spots that are inwardly bluntly pointed and outwardly rounded, brighter than in $X$. crotonis (Fig. 4A). Underside pattern similar to forewing, but ground colour paler. Basalmost two medial lines continuous, diffuse and pale brown; outermost medial line represented only by black dots on the veins; inner edge of marginal area more continuous and darker than forewing and hardly produced inward on vein $\mathrm{M}_{2}$ (Fig. 4B).

Abdomen. Upperside with three interrupted dark lines, posterior end of tergites darker. Underside pale orangeyellow.

Genitalia. Male genitalia (Fig. 5) similar overall to other species of the Xylophanes crotonis species-group. Uncus setose, thin and slightly more elongate and pointed than in $X$. crotonis. Gnathos claw-shaped, with a dorsally serrate apex. Valva oval, densely covered with setae (Figs 5A-B). Harpe shape unique within the species-group in being relatively short and straight with only a very slightly upcurved and blunt apex. It is more robust and less pointed than in $X$. crotonis, and more robust and much less apically hooked than in $X$. pijao sp. $\mathrm{n}$. The dorsal margin is much more irregularly crenulated compared with $X$. crotonis, but the teeth are smaller and blunter than in X. pijao sp. n. Phallus (Figs 5C-D) with apical sclerotized process larger, broader and less oblique than in $X$. crotonis; left arm very similar to that of $X$. crotonis but the apical lobe more triangular and sharply pointed and lacks the tooth on the anterior concave margin that is present in $X$. crotonis; right lobe shorter, broader and distinctly more toothed than in X. crotonis. Female genitalia unknown.

Type material. Holotype $\delta^{\lambda}$, Colombia, Magdalena, Cerro Kennedy, Minca to Cerro Kennedy, $11.095^{\circ} \mathrm{N} 74.0784^{\circ} \mathrm{W}$, 1600 m, 01.xii.2016, BOLD SampleID 2CO-1355, Rougerie et al. leg., access. no. IAvH-E 186517, in coll. IAVH. Paratypes:

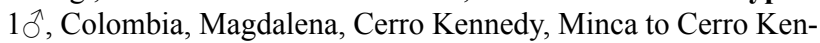
nedy, antenna station El Ramo, $11.1041^{\circ} \mathrm{N} 74.0591^{\circ} \mathrm{W}, 2500 \mathrm{~m}$, 19.30 h, 28.xi.2016, BOLD SampleID 2CO-0222, Rougerie et al. leg., in MNHN (under accession number IAvH-E 186499). $3 \stackrel{ }{\AA}$, Colombia, Magdalena, Cerro Kennedy, Minca to Cerro Kennedy, antenna station El Ramo, $11.104^{\circ} \mathrm{N} 74.056^{\circ} \mathrm{W}, 2500 \mathrm{~m}, 19.30$ h, 28.xi.2016, Rodolphe Rougerie leg., two of these in MNHN (under access. no IAvH-E186694, and IAvH-E186491), and 1 in IAVH (access. no. IAvH-E186431). 10, Colombia: Magdalena, Sierra Nevada de Santa Marta, $1400 \mathrm{~m}, 10^{\circ} 54^{\prime} \mathrm{N}, 74^{\circ} 03^{\prime} \mathrm{W}$, 3.vii-2.ix.1973, 265, Oxford Exped[itio]n to Colombia [leg.], B.M. 1973-500, BMNH(E) 1378207, [genitalia preparation] vial NHMUK010402236, in NHMUK. 10, Colombia, Dept. Magdalena, Valparaiso, $4000 \mathrm{ft}$, H.H. Smith [leg.], det. by W.J. Kaye, Levick Bequest B.M. 1941-83, BMNH(E) 1378208", in NHMUK.

Type locality. Colombia, Magdalena department, Cerro Kennedy, $11.095^{\circ} \mathrm{N}, 74.0784^{\circ} \mathrm{W}, 1600 \mathrm{~m}$.

Etymology. This species is dedicated to Camila González, a Colombian researcher at Universidad de Los Andes-Colombia, who participated in collecting in the SNSM and without whom that trip would not have been possible.

Distribution. Sierra Nevada de Santa Marta, Magdalena department, Colombia (Figs 6, 7A-B).

DNA barcode. Two specimens of Xylophanes camilae sp. $n$. have been DNA barcoded (see Table 1 and type specimen list above). Analysis of these sequences (see Fig. 3 and Table 2) shows that $X$. camilae $\mathrm{sp} . \mathrm{n}$. is genetically distinct from all other species in the $X$. crotonis species-group, forming BIN BOLD:ADG0023. Its nearest neighbour is $X$. virescens (BIN BOLD:AAB4963) with a minimum divergence of $3.8 \%$.

Comments. Over the last decade, many sphingid lovers, as well as some birders, have circulated numerous photographs of specimens of this species, all from the El Dorado Bird Reserve in the Sierra Nevada de Santa Marta, a famous site for ecotourism. Among the curious were Brian Fletcher, Alan Martin, Joakim Johansson and Janet Zinn. During this time, the question was always "what is this?", 


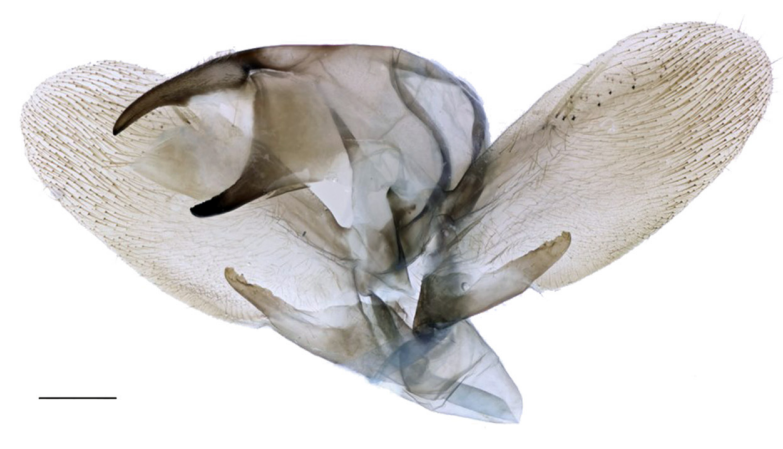

A

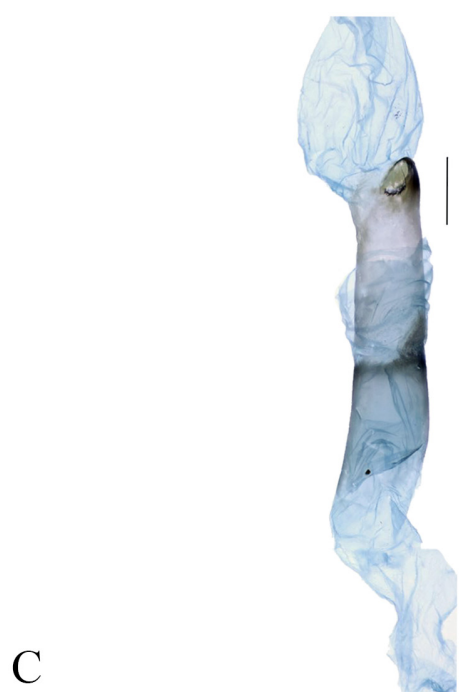

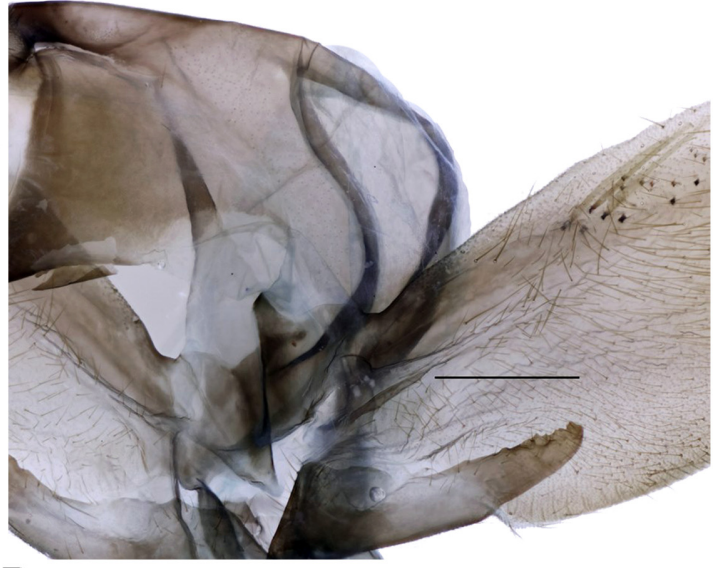

B

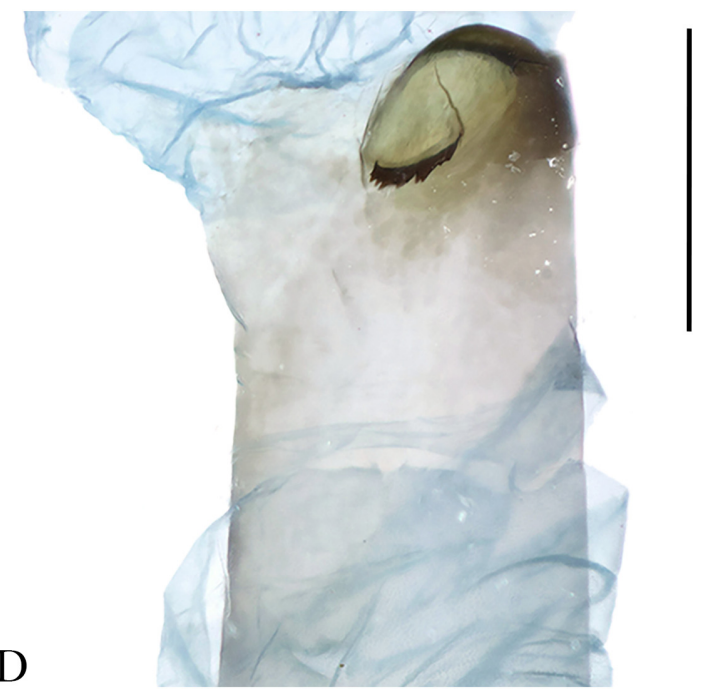

Fig. 5. Xylophanes camilae sp. n. paratype $\lesssim B M N H(E)$ 1378207. Male genitalia. A - valvae open ventral view; $B-$ right valva detail; $\mathrm{C}-$ phallus, dorsal view; D - phallus detail, dorsal view. Scale bars: $1 \mathrm{~mm}$.

and the answer was always "an undescribed species". Until now, the lack of recently collected specimens to study had prevented the species being described and named, a failing that this paper finally redresses.

\section{Xylophanes pijao Giusti \& Correa-Carmona, sp. n.}

ZooBank taxon LSID:

6A9B77CB-D96E-4AF6-B50B-8E386DF5B062

\section{Description}

Body length of $55 \mathrm{~mm}$.

Head and thorax. Upperside dark olive-green. Upperside thorax with a pale-yellow medial line, with pale yellow tegulae outer margins. Underside pale orange and brown.

Wings. Wingspan of $96 \mathrm{~mm}$. General mottled appearance, with upperside dark olive-green; and underside pale orange and brown. Forewings: Apex bluntly pointed, very slightly falcate; outer margin entire. Upperside dark olivegreen color, discal spot small; seven parallel oblique lines, three medial, three postmedial and one submarginal, all originating from the posterior margin and directed towards the apex; the three medial lines in the lighter part of the wing do not end at the apex but stop just short of the costa; the fourth line (first postmedial line) is thickest and darkest, also does not end at the apex but curves inward just before to end on the costa; the other two postmedial lines merge distally and end at the apex; submarginal line vague and broken into a series of individual or small groups of dark scales; area between the fourth line and the outer margin darkest. Underside extreme base pale, otherwise basal half black and costal area pale orange; discal spot pale, elongate reniform with a dark centre; three black, irregular medial lines, becoming diffuse near to the anal margin and thicker close to the apex; marginal patch paler, inner edge dark brown, strongly produced inward on vein $\mathrm{M}_{2}$, including numerous short black dashes arranged roughly parallel to outer margin. Hindwings: Upperside anal area light brown black, with a series of pale-yellow ovoid spots that are inwardly bluntly pointed and outwardly rounded, and a few scattered black scales inside each one (Fig. 8A). Underside pattern similar to underside forewings, the three medial lines more diffuse and broken, basal and submarginal areas pale orange, the inner edge of the marginal area more irregular than forewing and less strongly produced inward on vein $\mathrm{M}_{2}$ (Fig. 8B). 


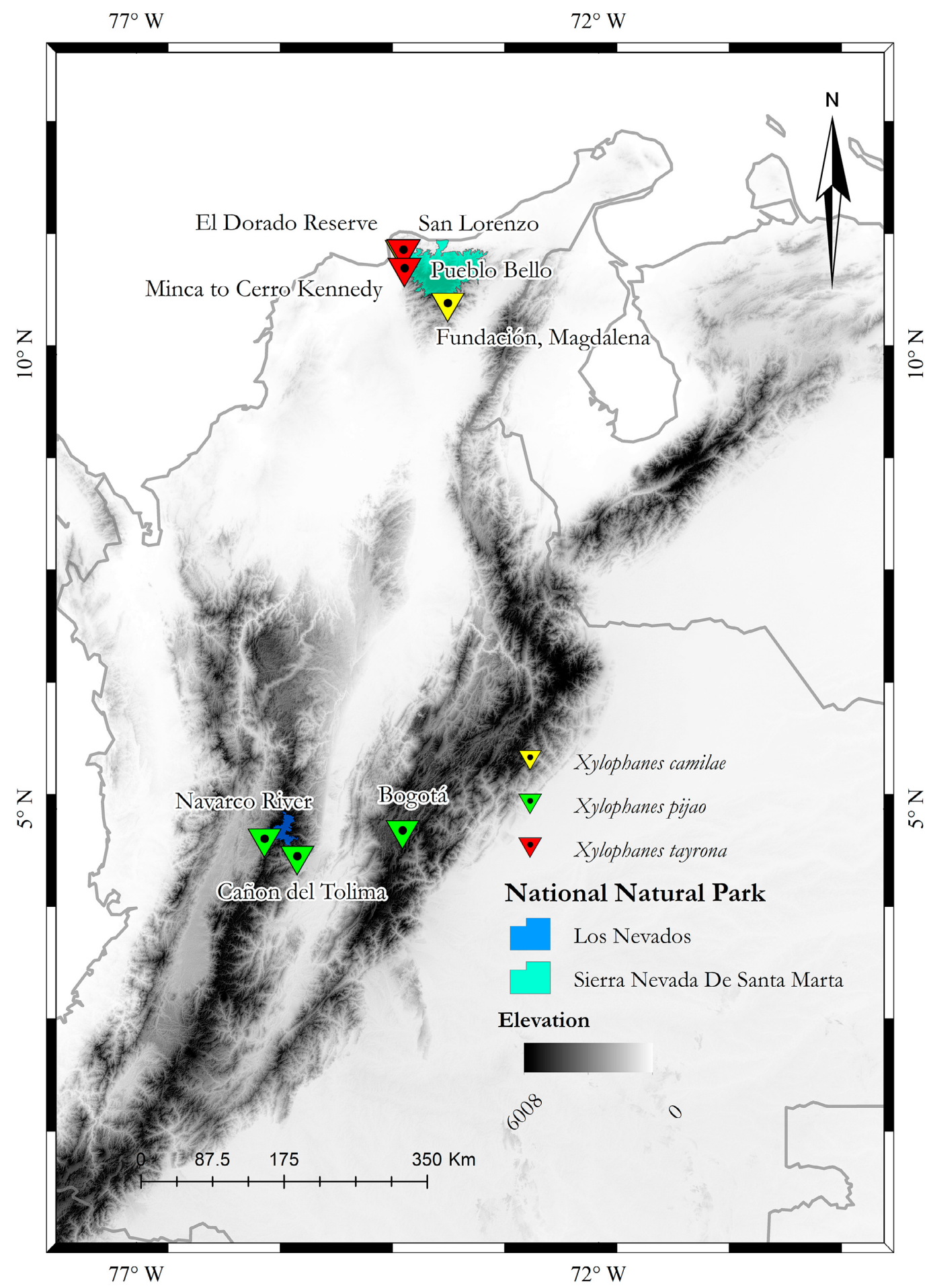

Fig. 6. Map of Colombia indicating the type localities of Xylophanes camilae sp. n., Xylophanes pijao sp. n., and Xylophanes tayrona sp. n.

Abdomen. Upperside with three dark medial lines, the central line slightly wider. Upperside abdomen light brown.

Genitalia. Male genitalia (Fig. 9) similar overall to other species of the Xylophanes crotonis species-group. Uncus setose, thin, elongate and, in dorsal view, similar to that of $X$. huloti but with a longer perceived split between the two basal branches, a narrower apex, less downwardly curved, and with a modest median indentation. Gnathos clawshaped, with a dorsally serrate apex. Valvae ovoid, broad and densely covered in setae. Harpe similar in size and shape to that of $X$. huloti but apical section slimmer, more pointed and hooked, dorsal edge with fewer teeth than in $X$. huloti. Phallus (Fig. 9C, D) with apical sclerotized process more curved than in $X$. huloti; left arm ending in a short, sharp triangular projection rather than a more-orless curved hook as in $X$. huloti; right arm broad, bluntly pointed, outer margin smooth, inner margin with several large teeth that are larger, deeper and more numerous and sclerotized than in $X$. huloti. Female genitalia unknown. 

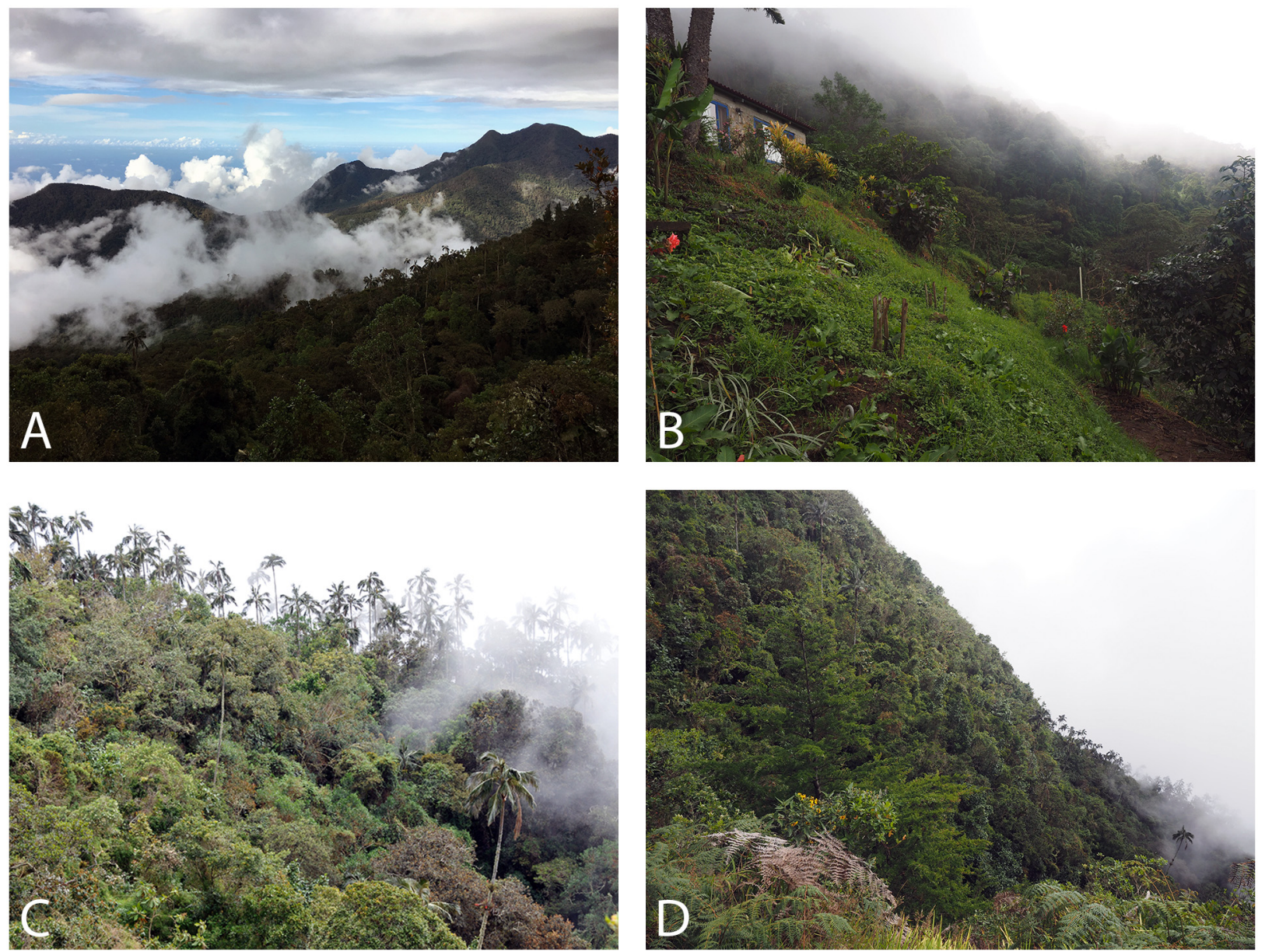

Fig. 7. Habitat of type localities in the Sierra Nevada de Santa Marta, Colombia. A and B - Xylophanes camilae sp. n.; C and D - Xylophanes tayrona sp. n. Photographs: R. Rougerie (A, B, D), T. Decaëns (C).

Type material. Holotype $\hat{\sigma}$, Colombia, Monte Tolima, 3200 m, January 1910, A.H. Fassl [leg.]., Rothschild Bequest B.M. 1939-1., BMNH(E) 1378211, [genitalia preparation] vial NHMUK010402234, in NHMUK. Paratypes: $1 \hat{O}^{\lambda}$, Colombia, Monte Tolima, 3200 m, January 1910, A.H. Fassl [leg.], Rothschild Bequest B.M. 1939-1., BMNH (E) 1378209. 1Ō , Colombia, Monte Tolima, 3200 m, January 1910, A.H. Fassl [leg.]), Rothschild Bequest B.M. 1939-1., BMNH (E) 1378213. 10 , Colombia, Monte Tolima, 3200 m, February 1910, A.H. Fass1 [leg.], Rothschild Bequest B.M. 1939-1., BMNH(E) 1378212. 10, Colombia, Monte Tolima, 3500 m, February 1910, A.H. Fass1 [leg.], Rothschild Bequest B.M. 1939-1., BMNH(E) 1378210. 10े, Colombia, Cañon del Tolima, 2700 m, December 1909, A.H. Fassl [leg.], Rothschild Bequest B.M. 1939-1., BMNH(E) 1378214.1 ठð, Colombia, Bogota, Xylophanes 65-2 crotonis Wlk. [hand-written label], Levick Bequest B.M. 1941-83, BMNH(E) 1378215. 1ठ, Colombia, Rio Navarco [hand-written label], det. by W.J. Kaye, Levick Bequest B.M. 1941-83, BMNH(E) 1378217. 10, [Colombia,] Bogota, Rothschild Bequest B.M. 1939-1., BMNH(E) 1378216. All in NHMUK.

Type locality. Colombia, Tolima department, Nevado del Tolima, $3200 \mathrm{~m}$.

Etymology. This species is dedicated to the indigenous Pijao people of the Department of Tolima and nearby regions in Colombia. The specific epithet is to be treated as a noun in apposition.

Distribution. Nevado del Tolima, central Andes, and Bogotá, east Andes, Colombia (Fig. 6).
DNA barcode. Due to the specimens being collected more than 100 years ago, and not being re-collected, it was not possible to extract any DNA.

Comments. Some specimens examined found in the NHMUK were collected by Anton Heinrich Fassl in 1910 in a locality referred to on the specimen labels simply as "Monte Tolima", now the Nevado del Tolima volcano in Central Andes, within the Los Nevados National Natural Park. Fassl (1911) briefly described the expedition carried out in 1910 in the western Andes, indicating that the type locality is at approximately $3000 \mathrm{~m}$ on the Monte Tolima, and that the forests above $2500 \mathrm{~m}$ are those with the greatest diversity of species, resulting in a particularly rich high mountain fauna, but the precise location has not been determined.

\section{Xylophanes tayrona Correa-Carmona \& Giusti, sp. n.}

ZooBank taxon LSID:

5652743B-07CB-4492-AAB8-5488EB90B143

\section{Description}

Body length of $55 \mathrm{~mm}$.

Head and thorax. Upperside brown-green, with tegulae grey outer margins and a thin, longitudinal yellow line, apically pale yellow. Thorax with a pale beige medial line with a diffuse brown-green central line, extending onto the abdomen. Underside thorax pale orange. 

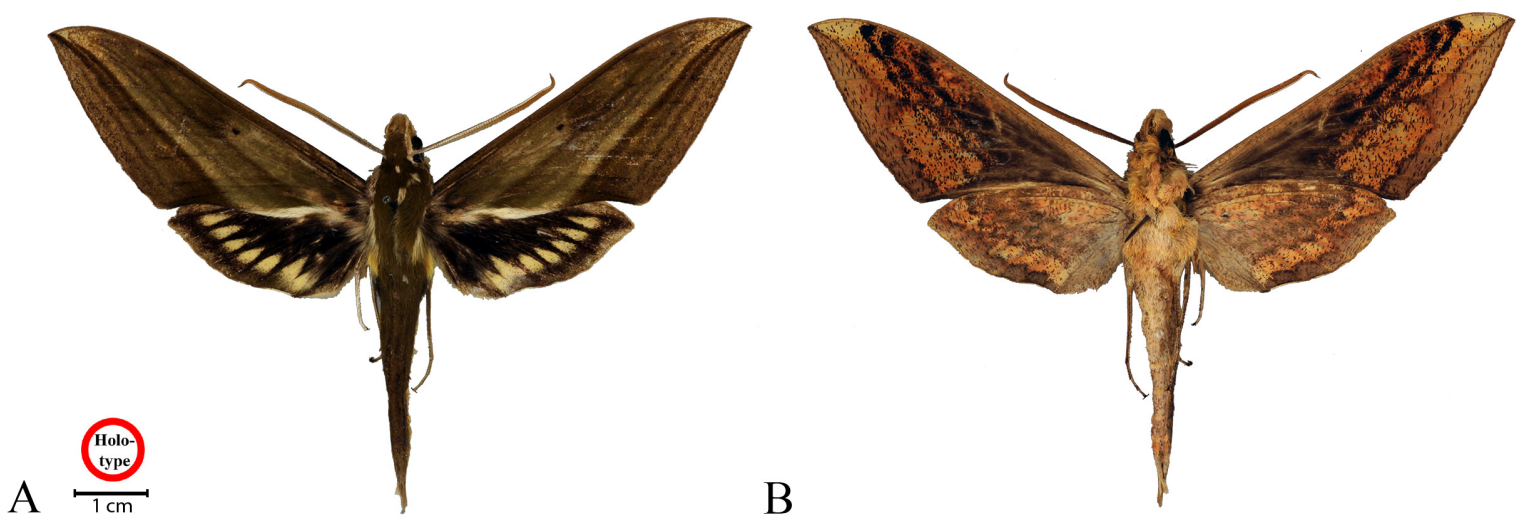

Fig. 8. Xylophanes pijao sp. n. holotype $\widehat{B} \mathrm{BMNH}(\mathrm{E})$ 1378211. A - upperside; $\mathrm{B}$ - underside.

Wings. Wingspan of $95 \mathrm{~mm}$. Upperside brown-green, with a general mottled appearance. Underside wings pale orange, with the anal area of hindwings beige. Forewings: Apex bluntly pointed, very slightly falcate; outer margin entire. Upperside with discal spot small and ovoid; seven parallel, slightly sinuate oblique lines, three medial, three postmedial and one submarginal, all originating from the posterior margin and directed towards the apex; the three medial lines all stop just short of the costa, of which the basal most is thicker and darker than the other two; the three postmedial lines merge together at the apex, of which first postmedial line (fourth line) is thickest and darkest; the space between the third and fourth lines lighter, as in $X$. aristor; submarginal line more diffuse, composed of a dense broken line of dark scales. Underside costal area pale brown; discal spot pale, comma-shaped with a dark centre;
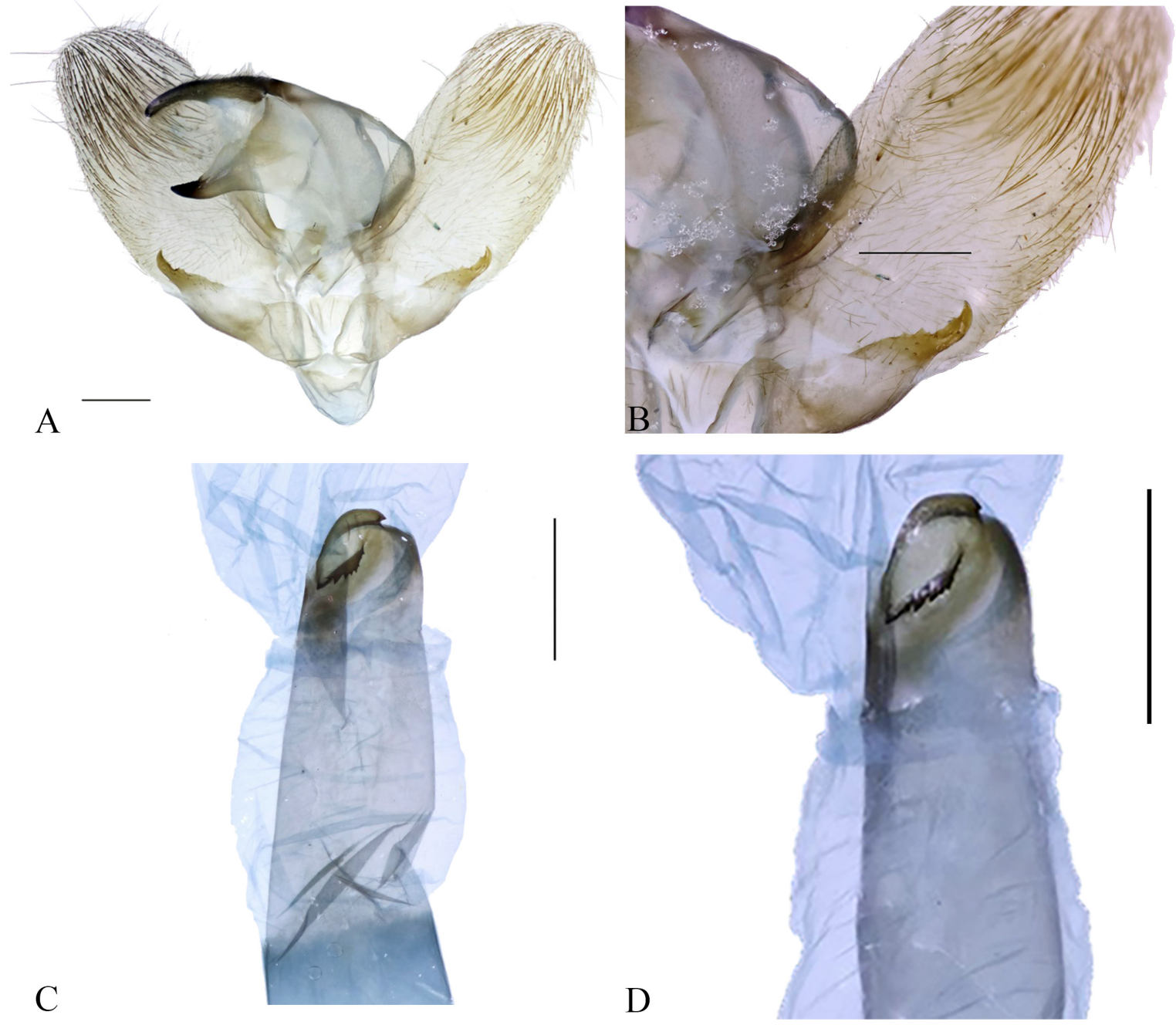

Fig. 9. Xylophanes pijao sp. n. holotype ${ }^{\lambda} \mathrm{BMNH}(\mathrm{E})$ 1378211. Male genitalia. A - valvae open ventral view; $\mathrm{B}$ - right valva detail; $\mathrm{C}-$ phallus, dorsal view; D - phallus detail, dorsal view. Scale bars: $1 \mathrm{~mm}$. 

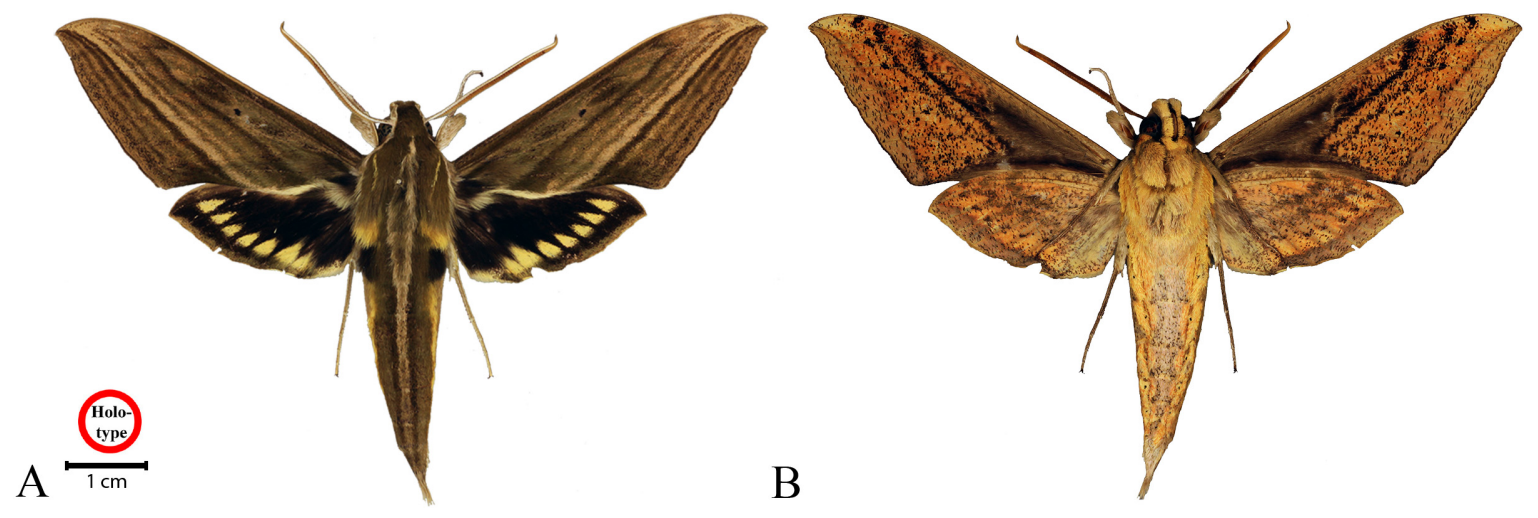

Fig. 10. Xylophanes tayrona sp. n. holotype ${ }^{\circledR} \mathrm{BMNH}(\mathrm{E})$ 1378196. A - upperside; $\mathrm{B}$ - underside.

a dark brown line running along the posterior margin, gradually narrowing towards and ending just before the tornus; three black medial lines run from the posterior margin to the costa, the first (basalmost) thick and continuous, the second more diffuse and breaking up into smaller black spots, and the third represented only by black spots on the veins; marginal patch paler, inner edge pale brown, irregular, only very slightly produced inward on vein $\mathrm{M}_{2}$, including relatively few short black dashes arranged roughly parallel to outer margin. Hindwings: Upperside deep dark, with a series of seven pale-yellow triangular spots that are inwardly sharply pointed and outwardly truncate, and a few scattered black scales inside each one; marginal area olive green (Fig. 10A). Underside pattern similar to forewing, but basal half pale orange (not black), the first two medial lines weaker and more diffuse, and the inner edge of the marginal area slightly broader and more diffuse (Fig. 10B).

Abdomen. Upperside brown-green with a pale beige line with a diffuse brown-green central line, bordered by two black lines. Underside beige color.

Genitalia. Male genitalia (Fig. 11) similar overall to other species of the Xylophanes crotonis species-group. Uncus setose, thin, elongate, slightly enlarged apically in lateral view. Gnathos claw-shaped, apex only slightly serrate dorsally. Both uncus and gnathos more curved compared with $X$. crotonis, $X$. aristor and the two preceding new species. Valva oval, with a dense covering of setae (Figs 11A-B). Harpe characteristically more strongly hooked than in any other species of this species-group; dorsal margin strongly concave with a pronounced triangular basal tooth, a sharply upcurved apex, and several teeth along the dorsal margin. The shape of the harpe is most similar to that of $X$. mineti mineti Haxaire \& Vaglia, 2004, but in that species, the dorsal margin is not as deeply concave and the basal tooth is not as pronounced. Phallus (Figs 11C-D) sclerotized and more pointed than in the two preceding species; apical sclerotized process similarly oval but more elongate than in the preceding species and $X$. aristor; left arm similar to $X$. crotonis, particularly in having a small, sharp tooth on the anterior concave margin, although this is larger in Xylophanes tayrona sp. n.; right arm elongate, as in $X$. crotonis, but slightly thicker and oriented more obliquely, with the anterior margin more irregularly toothed compared with $X$. crotonis. Female genitalia unknown.
Type material. Holotype $\hat{\jmath}$, Colombia, Magdalena, Sierra Nevada de Santa Marta, Hotel Solito, 2300 m, 12.xii.1974 [handwritten], at Tilley lamp, C. Gibson [leg.], B.M. 1976-712., BMNH(E) 1378196, [genitalia preparation] vial NHMUK010402235. In

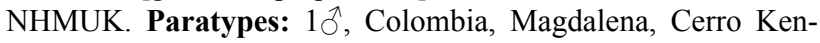
nedy, Minca to Cerro Kennedy, antenna station El Ramo, $11.1023^{\circ} \mathrm{N}, 74.0617^{\circ} \mathrm{W}, 2400 \mathrm{~m}, 22.00 \mathrm{~h}, 29 . x i .2016$, BOLD SampleID 2CO-1139, Rougerie et al. leg., in IAVH (acc. code IAvH-E 186511). 1 $\delta^{\lambda}$, same collecting data, BOLD SampleID RROU00395, in MNHN (IavH-E 186512). 1ðð, Colombia, Magdalena, Sierra Nevada de Santa Marta, Hotel Solito, $10^{\circ} 54^{\prime} \mathrm{N}$, 7400’W, 2300 m, 12/12/74, 3001, C. Gibson Coll. [leg.], BMNH 1976-716, BMNH(E) 1378197. 1ð̃, Colombia, Magdalena, Sierra Nevada de Santa Marta, Hotel Solito, $10^{\circ} 54^{\prime} \mathrm{N}, 74^{\circ} 00^{\prime} \mathrm{W}$, 2300 m, 12/12/74, 3002, C. Gibson Coll. [leg.], BMNH 1976716, BMNH(E) 1378198. All in NHMUK.

Type locality. Colombia, Magdalena department, Sierra Nevada de Santa Marta, Hotel Solito, $2300 \mathrm{~m}$.

Etymology. This species is dedicated to the Tayrona, one of the pre-Columbian cultures and the first people who lived in the Sierra Nevada de Santa Marta, and to the national park covering the same region. The specific epithet is to be treated as a noun in apposition.

Distribution. Sierra Nevada de Santa Marta, Magdalena department, Colombia (Figs 1, 2C-D).

DNA barcode. Two specimens of Xylophanes tayrona sp. n. have been DNA barcoded (see type specimen list above). Analysis of these sequences (see Fig. 3 and Table 2) shows that Xylophanes tayrona sp. n. is genetically distinct from all other species in the $X$. crotonis species-group, forming BIN BOLD:ADG0325. Its nearest neighbour is $X$. alexandrei (BIN BOLD:AAB4963) with a minimum divergence of $3.1 \%$.

\section{Key to the new species and the three most closely similar species, $X$. aristor, $X$. crotonis and $X$. huloti}

The Xylophanes crotonis species-group comprises large (wingspans generally $>8 \mathrm{~cm}$ ) species with the folowing combination of characters: forewing upperside ground colour green (though fading to brown in old specimens or those that have been subjected to high humidity); medial band of the hindwing upperside formed of a series of pale yellow triangular spots; the brown marginal bands of the forewing and hindwing undersides contrast, at least somewhat, with the orange ground colour; and the abdomen on each side with a yellow tuft, followed by a rectangular 

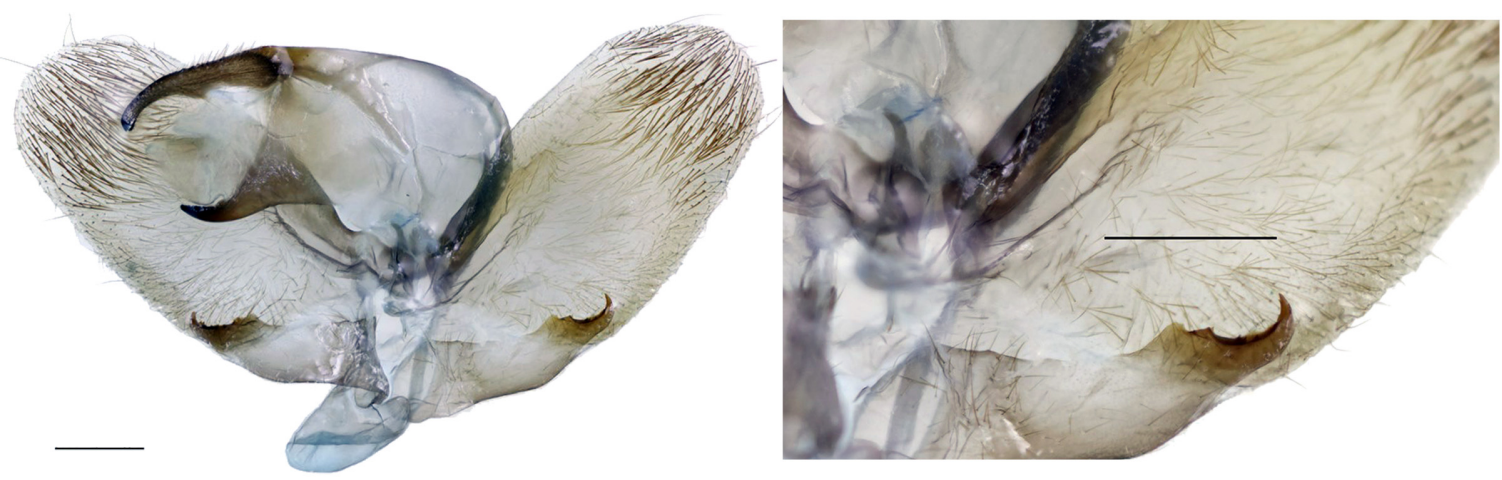

A

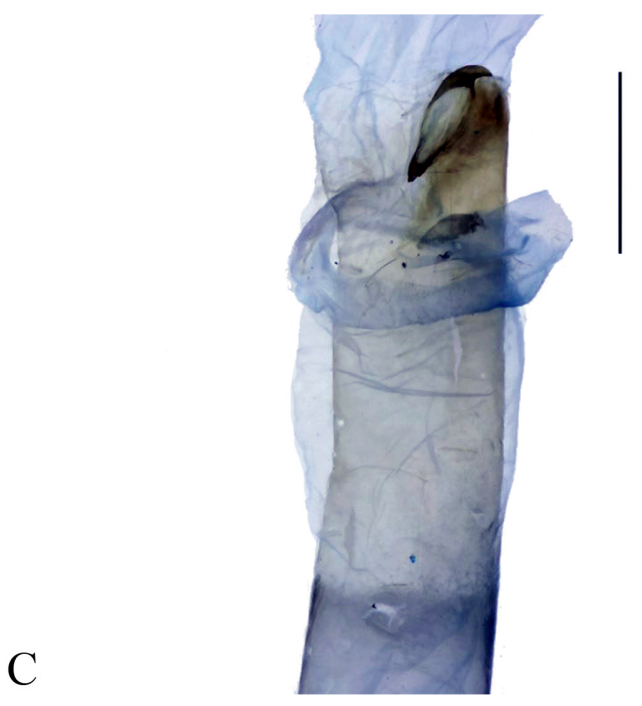

B

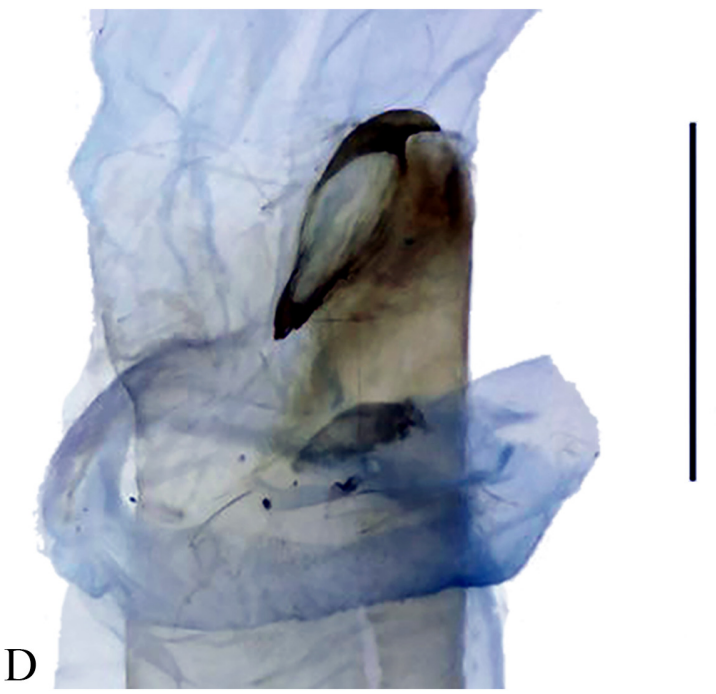

Fig. 11. Xylophanes tayrona sp. $\mathrm{n}$. holotype $\widehat{C} \mathrm{BMNH}(\mathrm{E})$ 1378196. Male genitalia. A - valvae open ventral view; $\mathrm{B}$ - right valva detail; $\mathrm{C}$ - phallus, dorsal view; D - phallus detail, dorsal view. Scale bars: $1 \mathrm{~mm}$.

black spot and then an elongate golden-yellow stripe. This key serves to distinguish among the three new species described here and the three most similar species of the $X$. crotonis species-group.

1 Abdomen with two dark longitudinal dorsal lines and a median pale band (Fig. 12A-i)

- Abdomen with three dark longitudinal abdominal dorsal lines, possibly discontinuous but never with the median band pale (Fig. 12A-ii)

2 Dark oblique lines of forewings slightly sinuate (Fig. 12B-i) ..Xylophanes tayrona sp. $\mathrm{n}$

- Dark oblique lines of forewings entire or not sinuated (Fig. 12B-ii). Xylophanes aristor

3 Thorax with pale yellow tegulae outer margins (Fig. 12C-i).

- Thorax without pale yellow tegulae outer margins (Fig. $12 \mathrm{C}$-ii)

4 Dorsal forewings dark olive-green, with darkly suffused pattern, giving the wing a somewhat "dirty" appearance (Fig. 12D-i) Xylophanes pijao sp. $\mathrm{n}$.

- Dorsal forewings dark green, with a "cleaner" more uniform pattern (Fig. 12D-ii) Xylophanes huloti

5 Dark oblique lines of forewings and longitudinal dorsal lines of abdomen discontinuous, appearing punctate (Fig. 12E-i).. Xylophanes camilae sp. $\mathrm{n}$.
- Dark oblique lines of forewings and the longitudinal dorsal lines of abdomen continuous (Fig. 12E-ii).

Xylophanes crotonis

\section{DISCUSSION}

Through the use of an integrative approach combining morphological comparisons and DNA barcoding, the present study has revealed the existence of three new species within the Xylophanes crotonis species-group. This group is the most speciose within the genus and its species are notoriously difficult to identify morphologically. The results presented here from the analysis of DNA barcodes support unequivocally the distinction of all species within the species-group (including those previously described), and demonstrate the consistency of the morphological characters proposed to distinguish two of the new species for which we have DNA barcodes. The use of the standard DNA barcode region in an integrative framework has already proved to be an efficient approach in Lepidoptera (Hebert et al., 2010; Hausmann et al., 2011; Janzen et al., 2012; Huemer et al., 2014; Zahiri et al., 2014), including in genus Xylophanes within family Sphingidae (Vaglia et al., 2008). By using several lines of evidence (morphological, ecological, genetic), the biases inherent in each set of 


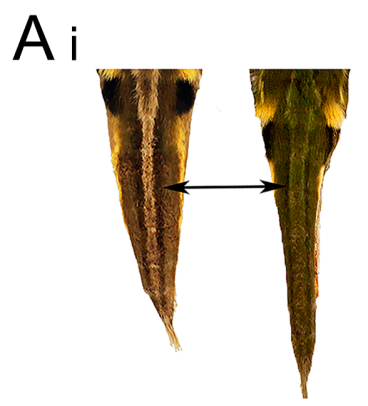

Two dark dorsal lines with a pale band in the middle ii

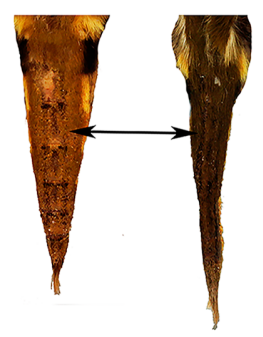

Three dark dorsal lines never with a pale band

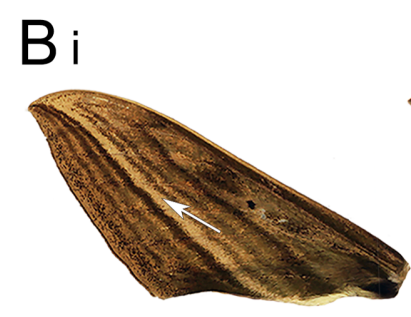

Slightly sinuate

Di

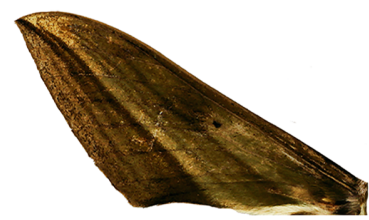

Dark olive-green, with darkly suffused pattern ii

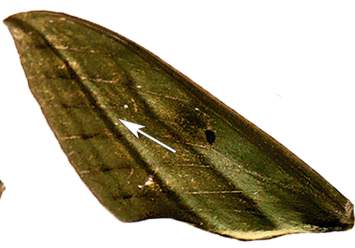

Entire or not sinuated
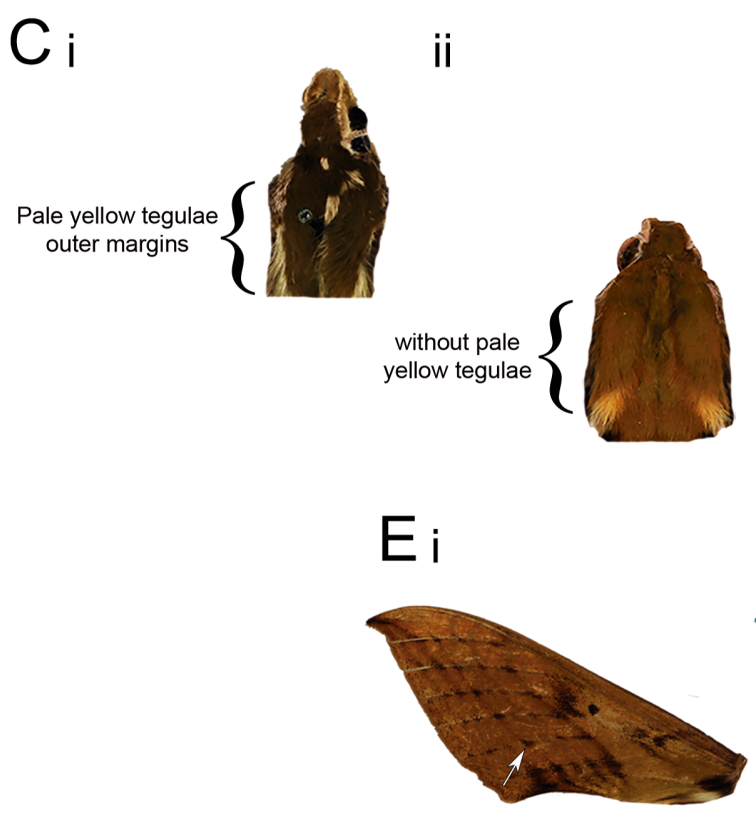

ii

Dark oblique lines discontinuous and appear punctate

Dark oblique lines continuous

Fig. 12. Morphological characters of Xylophanes species. A - dorsal lines of the abdomen: $i$ - pale band in the middle; ii - three dark dorsal lines. B - oblique lines of forewings: $\mathrm{i}$ - slightly sinuate; ii - entire or not sinuate. $\mathrm{C}$ - thorax detail at the outer margins: $\mathrm{i}$ - with pale yellow tegulae; ii - without pale yellow tegulae. D - colour of dorsal forewings: $\mathrm{i}$ - dark olive-green, with darkly suffused pattern; ii - dark green, with a more uniform pattern. E - oblique lines of forewings and dorsal lines of the abdomen: $\mathrm{i}$ - discontinuous, appearing punctate; ii - continuous.

characters [e.g., incomplete lineage sorting, pseudogenes or introgression or Wolbachia infection for genetic data (Rougerie et al., 2012; Smith et al., 2012; Mutanen et al., 2016); polymorphism or aberrant forms for morphological data] can be avoided.

The segregation of specimens based on morphology matches perfectly the clusters of DNA barcode sequences obtained (Fig. 1), and there is then no evidence from morphology for hybridization or introgression (as documented in other genera of macroglossine hawkmoths: Rougerie et al., 2012; Hundsdoerfer et al., 2019; Hundsdoerfer \& Kitching, 2020) that could result in incongruence between morphological and mtDNA-based species discrimination. This supports the reliability of DNA barcoding for the identification of species in the $X$. crotonis species-group (X. pijao sp. n. currently lacks a DNA barcode). As such our dataset represents an important contribution to future studies of this difficult group.

Colombia is one of the most diverse countries on earth, containing an array of biogeographical provinces, each with their own unique geological features. Among them, the Andean region can be considered the most diverse because of its mountainous complexes and the Páramo ecosystem, which exhibits a high level of endemism (Rangel, 2006; Morrone, 2014). Additionally, the Sierra Nevada de Santa Marta (SNSM) is the highest non-Andean mountain range in the Neotropics, and is an important component of the Tropical Andes biodiversity hotspot (Mittermeier et al., 2004; Alvear et al., 2015), containing one of the highest and most important levels of endemism in various groups, including plants, amphibians, birds, mammals, and insects in Colombia (e.g., Adams, 1973; Adams \& Bernard, 
1977; Anthelme et al., 2014; McMullan \& Donegan, 2014; González-Maya et al., 2016; Roach et al., 2020).

In confirmation, our results highlight the spectacular richness of the Colombian sphingid fauna. The most recent contribution to the knowledge of hawkmoths in Colombia reported 188 species (Correa-Carmona et al., 2015). However, it is believed that almost half of the country's fauna remains unexplored (Wolff et al., 2016) and further investigations, both in the field and in existing collections, will no doubt continue to reveal further discoveries of new sphingid species. All three species described here inhabit high elevation environments and highlight the need to explore the fauna of these mountain habitats thoroughly. This is especially critical in the current context of anthropogenic climate change, which can dramatically affect mountain biodiversity and cause species to become extinct before their discovery and their description. Importantly, our findings emphasize the uniqueness of the Sierra Nevada de Santa Marta, a centre of endemism (Cadena et al., 2015; Sanín, 2015), whose entomofauna remains largely unexplored, and where further discoveries surely await entomologists.

ACKNOWLEDGEMENTS. Sequencing of DNA barcodes for the Sphingidae global campaign were supported by grants from the Ontario Ministry of Research, Innovation and Science, the Canada Foundation for Innovation and Genome Canada to the Centre for Biodiversity genomics (University of Guelph, Ontario, Canada). The ANR grant SPHINX (ANR-16-CE02-0011-01) funded sequencing of newly collected Colombian specimens at the MNHN "Service de Systématique Moléculaire (SSM)", part of the Service Unit "Acquisition et Analyse de Données (2AD, UMS2700)". RR acknowledges the invaluable support by both C. González (Universidad de los Andes, Bogota) and M. González (Instituto von Humboldt, Bogotá), and members of their team, who helped organize collecting in SNSM in November-December 2016. This field collecting was a collective effort by RR and collaborators (namely M. Arias, E. Bacca, J. Barbut, T. Decaëns, C. Flautero, M. González, C. González, and G. Randazzo); it was supported by the MNHN "ATM Blanche" "LONOMIA" grant. We are also grateful to B. Vincent and D. Herbin for providing the neotype specimen of $X$. aristor that they collected in 2019 (ANLA no.01540,2019) with support from Prof. F. J. Serna Cardona and collaborators at Universidad Nacional, Facultad de Ciencias Agrarias in Bogotá and at Corporación Colombiana de Investigación Agropecuaria (AGROSAVIA). JH, IJK and RR are especially grateful to T. Melichar, U. Eitschberger and T. Vaglia, whose participation in the global DNA barcoding campaign for Sphingidae contributed many records, some of which were analysed in the present study. YCC is grateful to J. Herrera for her help and advice with the map, and to R. Canty and B. Huertas for their advice.

\section{REFERENCES}

ADAms M.J. 1973: Ecological zonation and the butterflies of the Sierra Nevada de Santa Marta, Colombia. - J. Nat. Hist. 7: 699-718.

Adams M.J. \& Bernard G.I. 1977: Pronophiline butterflies (Satyridae) of the Sierra Nevada de Santa Marta, Colombia. - Syst. Entomol. 2: 263-281.

Alvear M., Ocampo G., Parra C., Carbonó E. \& Almeda F. 2015: Melastomataceae of the Sierra Nevada de Santa Marta
(Colombia): floristic affinities and annotated catalogue. Phytotaxa 195: 1-30.

Anthelme F., Jacobsen D., Macek P., Meneses R.I., Moret P., BeCK S. \& Dangles O. 2014: Biodiversity patterns and continental insularity in the tropical High Andes. - Arctic Antarct. Alpine Res. 46: 811-828.

Borsduval J.B.A.E. DE 1870: Considérations sur des Lépidoptères envoyés du Guatemala à M. de l'Orza. Oberthür \& fils, Rennes, Paris, 100 pp.

BoIsDUval J.B.A.E. DE 1875: Histoire Naturelle des Insectes. Spécies Général des Lépidoptères Hétérocères. Vol. 1. Sphingides, Sésiides, Castnides. Librairie Encyclopédique de Roret, Paris, $568+4 \mathrm{pp}$.

ButLer A.G. 1876: Revision of the heterocerous Lepidoptera of the family Sphingidae. - Trans. Zool. Soc. Lond. 9: 511-644.

ButLer A.G. 1881: Illustrations of Typical Specimens of Lepidoptera Heterocera in the Collection of the British Museum. Vol. 5. British Museum, London, $74 \mathrm{pp.}$

Cadena C.D., Caro L.M., Caycedo P.C., Cuervo A.M., Bowie R.C.K. \& SLABBEKOORN H. 2015: Henicorhina anachoreta (Troglodytidae), another endemic bird species for the Sierra Nevada de Santa Marta, Colombia. _ Ornitol. Colomb. 15: 82-89.

CAdIOU J.-M. 1995: Seven new species of Sphingidae (Lepidoptera). - Lambillionea 95: 499-515.

Correa-Carmona Y., Vélez-Bravo A.H. \& Wolff E.M.I. 2015: Current status of knowledge of Sphingidae Latreille, 1802 (Lepidoptera: Bombycoidea) in Colombia. — Zootaxa 3987: $1-73$.

D'ABrera B. 1987: Sphingidae Mundi. Hawk Moths of the World. Based on a Checklist by Alan Hayes and the Collection He Curated in the British Museum (Natural History). E.W. Classey, Faringdon, $226 \mathrm{pp}$.

ESRI (Environmental Systems Resource Institute) 2016: ArcMap 10.4.1, ESRI, Redlands, California. URL: http://www. esri.com/ (last accessed 15 Nov. 2020).

FASSL A.H. 1911: Die vertikale Verbreitung der Lepidopteren in der Columbischen Central-Cordillere. - Fauna Exotica 7: 25-26.

GonzÁlez-Maya J.F., Arias-Alzate A., Granados-Peña R., Mancera-Rodríguez N.J. \& Ceballos G. 2016: Environmental determinants and spatial mismatch of mammal diversity measures in Colombia. - Anim. Biodiv. Conserv. 39: 77-87.

HAXAIRE J. 2003: Un nouveau Sphingidae d'Equateur Occidental: Xylophanes vagliai (Lepidoptera: Sphingidae). — Lambillionea 8: 659-662.

Haxaire J. \& Herbin D. 1999: Les Lépidoptères Sphingidae de Bolivie. Ecologie et systématique. 1ère Partie: sous-famille des Sphinginae Latreille. - Rev. Assoc. Rousillon. Entomol. 8: 69-79.

Haxaire J. \& Herbin D. 2000: Les Lépidoptères Sphingidae de Bolivie. Ecologie et systématique. 2ème Partie: les sous-familles des Smerinthinae et Macroglossinae pro parte (1). Rev. Assoc. Rousillon. Entomol. 9: 4-19.

HaXaire J. \& Herbin D. 2001: Les Lépidoptères Sphingidae de Bolivie. Ecologie et systématique. Suite et fin (Lepidoptera, Sphingidae). - Rev. Assoc. Rousillon. Entomol. 10: 80-95.

Haxaire J. \& Mielke C.G.C. 2018: Two new species of hawkmoth of the Xylophanes porcus (Hübner, [1823]) group from Brazil and Paraguay (Lepidoptera: Sphingidae). - Eur. Entomol. 9(2): 61-76.

HAXAIRE J. \& RASPLus J.-Y. 1986: Contribution à la connaissance des Sphingidae de Guyane Française. 1re Partie [Lep.]. — Bul. Soc. Entomol. Fr. 91: 275-285. 
HAXAIRE J. \& RAsPlus J.-Y. 1987: Contribution à la connaissance des Sphingidae de Guyane Française. 2e Partie [Lep.]. — Bul. Soc. Entomol. Fr. 92: 45-55.

Haxaire J. \& Vaglia P.T. 2004: Nouveaux Sphingidae équatoriens et boliviens du genre Xylophanes Hübner, [1819] (Lepidoptera, Sphingidae). — Lépidoptères 2(3): 27-33.

Haxaire J. \& VAgLia P.T. 2008: Un nouveau Sphingidae du genre Xylophanes Hübner, 1819: Xylophanes huloti sp. n. (Lepidoptera, Sphingidae). — Eur. Entomol. 1(2): 29-38.

Haxaire J., Rougerie R., Mielke C.G.C \& Kitching I.J. 2015: Manduca exiguus (Gehlen, 1942): a valid species from southern and southeastern Brazil, Uruguay and northeastern Argentina (Lepidoptera: Sphingidae). - Nachr. Entomol. Ver. Apollo (N.F.) 36(1): 49-54.

Hebert P.D.N., Penton E.H., Burns J.M., Janzen D.H. \& HaLlWACHS W. 2004: Ten species in one: DNA barcoding reveals cryptic species in the neotropical skipper butterfly $A s-$ traptes fulgerator. - Proc. Nat. Acad. Sci. 101: 14812-14817.

Hebert P.D.N., DeWaARd J.R. \& LandRy J.F. 2010: DNA barcodes for 1/1000 of the animal kingdom. - Biol. Lett. 6: 359 362.

Huemer P., Mutanen M., Sefc K.M. \& Hebert P.D.N. 2014: Testing DNA barcode performance in 1000 species of European Lepidoptera: Large geographical distances have small genetic impacts. - PLoS ONE 9(12): e115774, 21 pp.

Hundsdoerfer A.K. \& Kitching I.J. 2020: Ancient incomplete lineage sorting of Hyles and Rhodafra (Lepidoptera: Sphingidae). - Organisms Divers. Evol. 20: 527-536.

Hundsdoerfer A.K., Lee K.M., Kitching I.J. \& Mutanen M. 2019: Genome-wide SNP data reveal an overestimation of species diversity in a group of hawkmoths. - Genome Biol. Evol. 11: $2136-2150$

InTERNATIONAL COMMisSion on ZOOLOGICAL NomencLATURe (ICZN) 1999: International Code of Zoological Nomenclature. Fourth Edition. International Trust for Zoological Nomenclature, London, $\mathrm{xxx}+306 \mathrm{pp}$.

Janzen D.H., Hallwachs W., Harvey D.J., Darrow K., Rougerie R., Hajibabaei M., Smith M.A., Bertrand C., Gamboa I.C., EsPINOZA B. ET AL. 2012: What happens to the traditional taxonomy when a well-known tropical saturniid moth fauna is DNA barcoded? - Invertebr. Syst. 26: 478-505.

Jarvis A., Reuter H.I., Nelson A. \& Guevara E. 2008: Holefilled SRTM for the Globe. Ver. 4. Available from the CGIARCSI SRTM 90m Database. URL: http://srtm.csi.cgiar.org (last accessed 15 Nov. 2020).

KIRBY W.F. 1897: A handbook to the Order Lepidoptera. Volume 4 (Moths - Part II). Edward Lloyd, London, xlii + 246 pp.

KITCHING I.J. 2020: Sphingidae Taxonomic Inventory. URL: http://sphingidae.myspecies.info/ (last accessed 5 Nov. 2020).

Kitching I.J. \& CAdiou J.M. 2000: Hawkmoths of the World: An Annotated and Illustrated Revisionary Checklist (Lepidoptera: Sphingidae). The Natural History Museum, London \& Cornell University Press, Ithaca, $227 \mathrm{pp}$.

Kitching I., Rougerie R., Zwick A., Hamilton C., St Laurent R., Naumann S., Ballesteros Mejia L. \& Kawahara A. 2018: A global checklist of the Bombycoidea (Insecta: Lepidoptera). Biodiv. Data J. 6: e22236, 13 pp.

Krutov V., Ivshin N. \& Romanov D. 2021: New taxa of the "crotonis group" of the genus Xylophanes Hübner, [1819] (Lepidoptera, Sphingidae), with notes on related species. - Eur Entomol. 12[2020]: 37-87.

Kumar S., Stecher G., Li M., Knyaz C. \& Tamura K. 2018: MEGA X: Molecular Evolutionary Genetics Analysis across computing platforms. — Mol. Biol. Evol. 35: 1547-1549.
Lees D.C., Rougerie R., Zeller-LuKashort H.C. \& Kristensen N.P. 2010: DNA minibarcodes in taxonomic assignment: a morphologically unique new homoneurous moth clade from the Indian Himalayas described in Micropterix (Lepidoptera, Micropterigidae). - Zool. Scripta 39: 642-661.

Letunic I. \& Bork P. 2019: Interactive Tree Of Life (iTOL) v4: recent updates and new developments. - Nucl. Acids Res. 47: 256-259.

Lichy R. 1968: Documentos para servir al estudio de los Sphingidae de Venezuela (Lepidoptera, Heterocera) (12a nota). - Bol. Entomol. Venezol. 18: 31-42.

MAASSEN J.P. 1880: Bemerkungen zu der von A.G. Butler vorgenommenen Revision der Sphingiden. (Transactions of the Zoological Society of London 1877.). — Stettiner Entomol. Ztg 41: 49-72.

McMullan M. \& Donegan T. 2014: Field Guide to the Birds of Colombia. Fundación ProAves de Colombia, Bogotá, 225 pp.

MÉNÉTRIÉs E. 1857: Supplément à la Ire partie. In Ménétriés E. (ed.): Enumeratio Corporum Animalium Musei Imperialis Academiae Scientiarum Petropolitanae. Classis Insectorum Ordo Lepidopterorum Pars II. Lepidoptera Heterocera. Academiae Scientiarum Imperialis, Petropolitae, pp. 67-112 + [2] +99-144.

Mittermeier R.A., Robles-Gil P., Hoffmann M., Pilgrim J.D., Brooks T.M., Mittermeier C.G. \& FonseCa G. 2004: Hotspots Revisited: Earth's Biologically Richest and Most Endangered Ecoregions. 2nd ed. Cemex, Mexico, 391 pp.

Moré M., Kitching I.J. \& Cocucci A.A. 2005: Sphingidae: Esfingidos de Argentina / Hawkmoths of Argentina. L.O.L.A. (Literature of Latin America), Buenos Aires, 184 pp.

MoRrone J.J. 2014: Biogeographical regionalisation of the Neotropical region. - Zootaxa 3782: 1-110.

Mutanen M., Kivelä S.M., Vos R.A., Doorenweerd C., Ratnasingham S., Hausmann A., Huemer P., Dinca V., van Nieukerken E.J., LoPEZ-VAAMONDE C. ET AL. 2016: Species-level para- and polyphyly in DNA barcode gene trees: strong operational bias in European Lepidoptera. - Syst. Biol. 65: 1024-1040.

Rangel-ChuRio J.O. 2006: La biodiversidad de Colombia. Palimpsesto 5: 292-304.

Ratnasingham S. \& Hebert P.D.N. 2007: BOLD: The barcode of life data system (http://www.barcodinglife.org). - Mol. Ecol. Notes 7: 355-364.

RatNASINGHAM S. \& HeBERT P.D.N. 2013: A DNA-based registry for all animal species: the Barcode Index Number (BIN) System. - PLoS ONE 8(7): e66213, 16 pp.

RoACh N.S., Urbina-CARDona N. \& LACHER T.E. JR. 2020: Land cover drives amphibian diversity across steep elevational gradients in an isolated Neotropical mountain range: implications for community conservation. - Global Ecol. Conserv. 22: $1-14$.

RothSCHILD L.W. \& JoRDAN K. 1903: A revision of the lepidopterous family Sphingidae. — Novit. Zool. (Suppl.) 9: 1-972.

Rougerie R., Haxaire J., Kitching I.J. \& Hebert P.D.N. 2012: DNA barcodes and morphology reveal a hybrid hawkmoth in Tahiti (Lepidoptera: Sphingidae). — Invertebr. Syst. 26: 445450.

Rougerie R., Kitching I.J., Haxaire J., Miller S.E., Hausmann A. \& Hebert P.D.N. 2014: Australian Sphingidae - DNA barcodes challenge current species boundaries and distributions. - PLoS ONE 9(7): e101108, 8 pp.

SANín D. 2015: Serpocaulon tayronae (Polypodiaceae), a new fern species from the Sierra Nevada de Santa Marta. - Phytotaxa 213: 243-252. 
Schaufuss L.W. 1870: Die exotischen Lepidoptera Heterocera der Früher Kaden'schen Sammlung. - Nunquam Otiosus 1: $7-23$.

Smith M.A., Bertrand C., Crosby K., Eveleigh E.S., FernandezTriana J., Fisher B.L., Gibbs J., Hajibabaei M., Hallwachs W., HIND K. ET AL. 2012: Wolbachia and DNA barcoding insects: Patterns, potential, and problems. - PLoS ONE 7(5): e36514, $12 \mathrm{pp}$.

VAglia T. \& HAXAIRE J. 2009: Description d'un nouveau Sphingidae des Andes orientales, Xylophanes alexandrei (Lepidoptera, Sphingidae). - Eur. Entomol. 1: 103-110.

Vaglia T., Haxaire J., Kitching I.J., Meusnier I. \& Rougerie R. 2008: Morphology and DNA barcoding reveal three cryptic species within the Xylophanes neoptolemus and loelia speciesgroups (Lepidoptera: Sphingidae). - Zootaxa 1923: 18-36.

WALKER F. 1856: List of the Specimens of Lepidopterous Insects in the Collection of the British Museum. Vol. 8. Trustees of the British Museum, London, $271 \mathrm{pp}$.

WolfF M., Nihei S.S. \& De Carvalho C.J.B. 2016: Catalogue of Diptera of Colombia: an introduction. - Zootaxa 4122: 8-14.

Zahiri R., Lafontaine D., Schmidt C.D., Zakharov E. \& Hebert P.D.N. 2014: A transcontinental challenge - a test of DNA barcode performance for 1541 species of Canadian Noctuoidea. - PLoS ONE 9(3): e92797, 12 pp.

Received May 5, 2020; revised and accepted February 12, 2021 Published online March 19, 2021 